\title{
Applications and Thermal Management of Rechargeable Batteries for Industrial Applications
}

Hussam Jouhara ${ }^{* a}$, Navid Khordehgah ${ }^{a}$, Nicolas Serey ${ }^{\mathrm{a}}$, Sulaiman Almahmoud ${ }^{\mathrm{a}}$, Stephen P. Lester $^{\mathrm{b}}$, Daniel Machen ${ }^{\mathrm{c}, \mathrm{d}}$, Luiz Wrobel ${ }^{\mathrm{a}}$

a- College of Engineering, Design and Physical Sciences, Brunel University London, UB8 3PH, UK

b- Flint Engineering Limited, The Paddocks, Five Ashes, Mayfield, TN20 6JL, UK

c- Vantage Power Ltd, Unit 7 Ockham Drive, Greenford, UB6 0FD, UKDM Battery

d- Design Ltd, 15 Water Royd Drive, Dodworth, Barnsley, S75 3QX, UK 


\begin{abstract}
In this review, the operation and functionality of batteries used in industrial applications will be investigated. It will be discussed how and why batteries degrade and lose efficiency because of improper thermal management and based on that it will be explained what methods and techniques can be applied to reduce this impact. Through this, it will be explained how heat management methods could be used to thermally control batteries. In addition to this, it will be indicated what technologies can be employed to manage thermal boundaries of batteries. A comprehensive review of the current state of the art technologies currently used will be followed by that which will include how these technologies can be applied as thermal management systems for batteries.
\end{abstract}

\title{
1. Introduction
}

With the growing trend of increase in fuel prices and the ever-growing rising concern regarding greenhouse gas emissions, the engineering industry has developed an interest in using renewable energy sources and developing clean energy transport systems [1-2]. In this regard, the use of batteries has been regarded as one of the most important ways of transporting and storing electrical energy [3].

The rapid growth of energy demand which is associated with the rising global population has also promoted the need for more efficient and bigger energy storage systems [4]. On the other hand, targets set by governments and authorises such as Horizon 2020 by the European Union also calls for special attention towards developing more effective electrical storage systems [5-6]. In this respect during recent years, new batteries have emerged which offer promising energy storage technology with benefits such as higher gravimetric and volumetric energy density and lower self- discharge rate [7].

Within energy storage system design, it is investigated that factors such as temperature rise or fall, overheating, freezing and non-uniform temperature distribution between battery cells can negatively impact performance, safety and cycle lifetime of batteries. For instance, as Lin [8] discovers, a temperature range between -10 to $50^{\circ} \mathrm{C}$ has been reported as an optimum temperature range for a lithium-ion battery. However, a better performance from the battery has been observed in a more restricted range temperature range of +20 to $40^{\circ} \mathrm{C}$ [9]. Motloch [10] investigates that for every $1^{\circ} \mathrm{C}$ increase in Li-ion cell temperature in an operating range of 30 to $40^{\circ} \mathrm{C}$, the lifetime of the battery is reduced by approximately two months. From the research conducted by Zhang et al. [11] it can be discovered that the capacity of Li-ion batteries can decrease by almost 95\% when the cell is operating at a sub-zero temperature of $-10^{\circ} \mathrm{C}$ compared to that at $20^{\circ} \mathrm{C}$. Hutchinson [12] discovers for a lead acid battery the ideal operating temperature is in the range of $25-50^{\circ} \mathrm{C}$. It is explained that for a lead acid battery, for every $8^{\circ} \mathrm{C}$ rise in temperature, the battery life is cut in half. For instance this as can be seen from Figure 1, which shows how effective capacity of a lead acid battery is effected by temperature. 


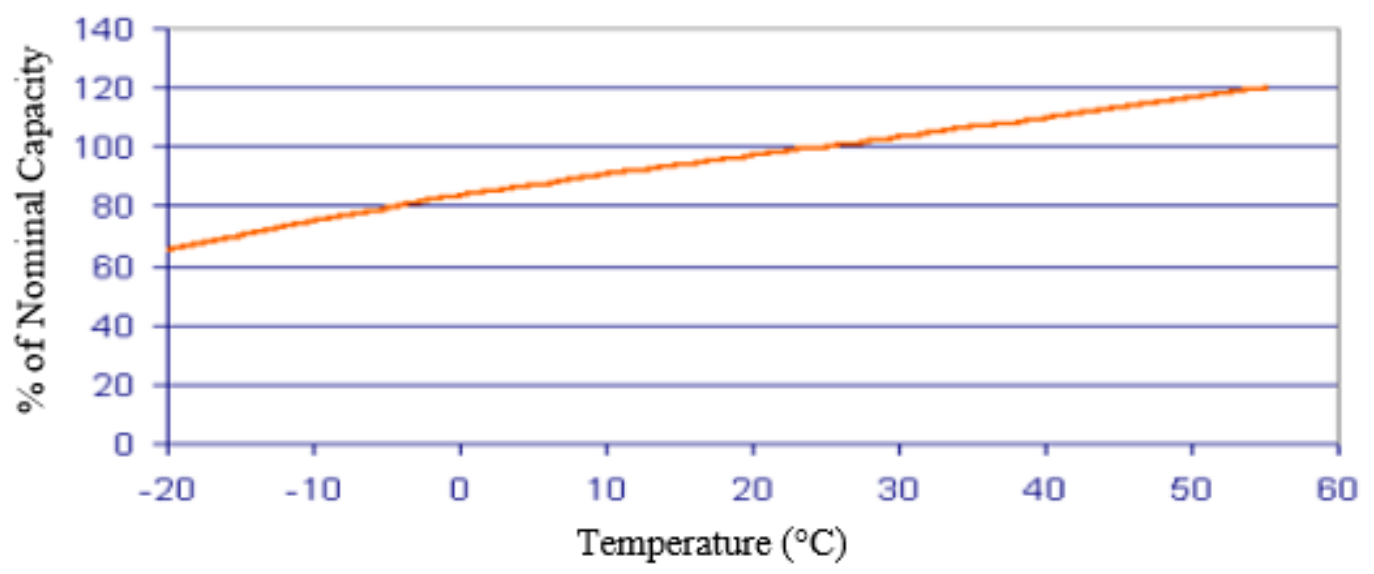

Figure 1. Effect of Temperature on Effective Capacity [12].

It is illustrated for nickel based batteries such as the nickel-cadmium (NiCd) and the nickel-metal hydride (NiMH) batteries, the operating temperature is in the range of -20 to $50^{\circ} \mathrm{C}$ for both charging and discharging [13]. However, the actual capacity of these batteries was reduced significantly when the temperature went below $10^{\circ} \mathrm{C}$ and above $30^{\circ} \mathrm{C}[14]$.

As Anderson [15] explains, depending on the type of battery and the material used to build the battery cells, a different temperature range and therefore a different thermal management system should be applied. Khan et al. [16] investigates that the optimum operating cell temperature range for most general batteries is near room temperature and between $15-35^{\circ} \mathrm{C}$.

It is explained by Cen et al. [17] that the chemical reaction which occurs in batteries during charging and discharging directly affects and depends on temperature. In simple terms, all batteries operate based on an electrochemical process and their performance largely depends on temperature. It is investigated that the electrochemical reaction within the batteries can be initiated by either voltage difference or temperature.

With respect to the temperature change within cells, Bernardi and Pawlikowsk [18] developed a model for approximating heating rate within a battery cell. The total heat generation rate, $Q$, is given as the summation of both irreversible and reversible heat generation. The irreversible heat generation, $Q_{i r r}$ is always exothermic and given by,

$$
Q_{\text {irr }}=I^{2} R_{i}
$$

where $I$ is the current, and $R_{i}$ is the internal resistance of the cell which comprises the sum of ohmic, activation and diffusion polarisation resistances.

The reversible heating component comprises reversible entropy change, enthalpy of mixing effects, phase change terms and heat capacity effects. Since the heat capacity of cells is largely constant throughout operation, this term is often simplified to an average value, whilst enthalpy of mixing effects and phase change terms are neglected for a simple approximation.

$$
Q_{r}=I T_{C} \frac{d V^{a v g}}{d T}
$$


It should be noted that the cells will lose some heat to the environment and this is given by,

$$
Q_{\text {con }}=-h A\left(T_{C}-T_{a}\right)
$$

where $h$ is the convective heat transfer coefficient and $A$ is the surface area for heat transfer. This gives rise to the formulation of a general energy balance equation which takes the form,

$$
M C_{P} \frac{d T}{d t}=I^{2} R_{i}+I T_{C} \frac{d V^{a v g}}{d T}-h A\left(T_{C}-T_{a}\right)
$$

Based on this theory, it can be explained that the hotter the battery, the higher the efficiency due to the reduction in cell internal resistance $R_{i}$. However, this results in an increase of unwanted electrochemical side reactions which in turn results in a number of negative impacts on cell performance such as higher self-discharge rate, increase in capacity loss, oxidation of anode and cathode materials and a marked reduction in cycle life [19-20]. This highlights the importance of temperature regulation within a battery cell and therefore the need also to understand the relative benefits of different thermal management techniques.

In this regard, several studies have been conducted on thermal management of batteries which investigate, develop and introduce techniques and technologies to thermally control the temperature range of battery cells and therefore improve their functionality and efficiency. Hutchinson [12] explains that thermal management of batteries is an important topic as temperature directly affects the power availability, driveability and durability of the battery cells.

Thermal management of batteries mainly includes the use of air cooling, liquid cooling, and phase change materials [21]. It is discovered that air and liquid cooling techniques are the most extensively used methods due to low cost and simple functionality advantages [19-23]. Nevertheless, it is investigated that other technologies that incorporate heat pipes have also been used to both heat and cool batteries and enhance the thermal management [24].

In this paper, different types of rechargeable batteries used in industrial applications will be studied. By considering how temperature will affect each type of battery, thermal management principles and state of the art technologies developed and used for several applications will be considered and analysed. From this, a conclusion of the topic will be obtained which will help to understand how and why thermal management of batteries for industrial applications is important and how it can be achieved.

In this regard, the functionality and applications of heat management techniques and methods will be investigated. Through a state of the art literature review, different types of batteries and their applications will be discovered and based on that it will be explained what technologies can be used to manage battery thermal boundaries.

\section{Functionalities and Types of Batteries}

A battery is a chemical self-contained pack that can produce a certain amount of electrical energy whenever and wherever it is needed [15]. Batteries are used in many types of equipment, appliances 
and even vehicles [25]. The basic unit which produces power inside a battery is called a cell [26] and compromises three main components, consisting of two electrodes that are made out of conductive materials known as the anode, the cathode and a chemical known as the electrolyte [27].

The anode which is connected to the negative end of the battery attracts electrons that are dissipated from a chemical reaction which takes place in the battery. This results in an electrical difference between the positively charged cathode and the negatively charged anode [28]. The electrolyte makes the battery conductive by helping the movement of ions from the anode to the cathode when discharging or in reverse when charging, and acts as a shield so that the electrons do not travel directly to the cathode when connected to a source [29].

For instance and as shown in Figure 2, in a typical dry cell battery, the chemical reaction that takes place between the zinc alloy, or the negatively charged anode inside the battery, results in an unstable build-up of the electrons which would flow towards the graphite core of the battery that works as the positively charged cathode. However, due to the existence of the ammonium chloride paste as the electrolyte, the electrons are kept from going straight from the anode to the cathode, preventing a cell short circuit condition. Nonetheless, when the circuit is closed (through a link), the electrons are able to get to the cathode, powering up a device such as a lamp [30].

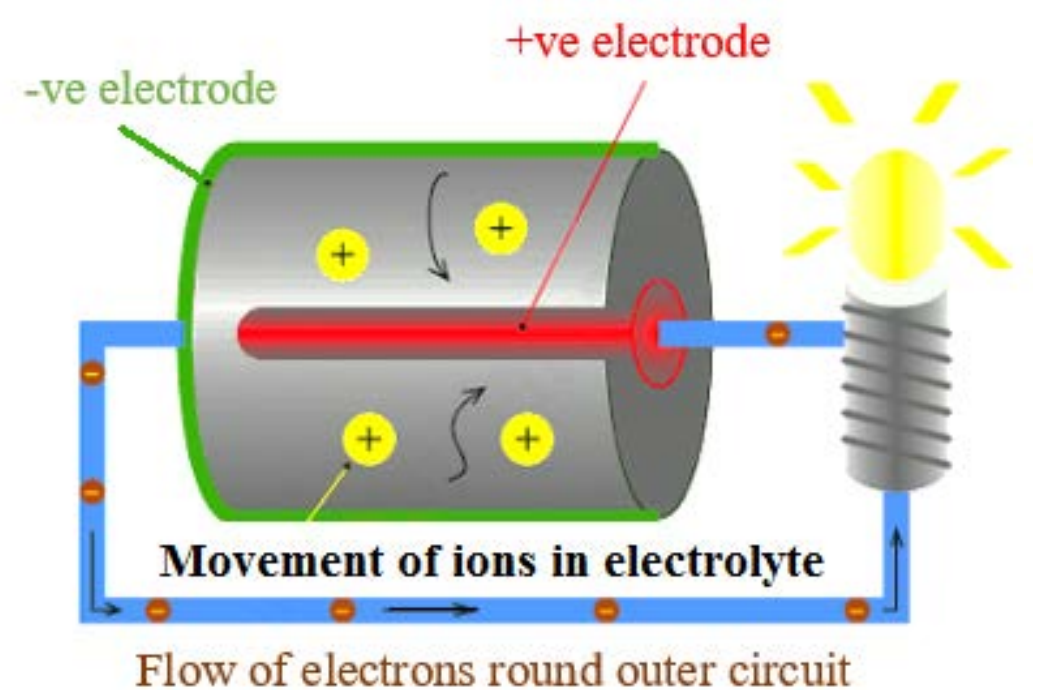

Figure 2. Internal Arrangements and Current Flow of a Dry Cell Battery [31].

Batteries in general are classified as primary or secondary depending on whether they are nonchargeable or rechargeable, respectively. A non-rechargeable battery is a battery which cannot be charged and needs to be disposed of when it is fully used. As can be seen from the table, these batteries are mostly used for domestic applications, seldom require thermal management and are considered to have a much shorter operating life than rechargeable batteries [32]. For the purpose of this report, only the functionality, application and the methods of thermal management for rechargeable batteries that are used in industrial applications will be investigated. As Broussely and Pistoia [33] explain, batteries such as lead-acid, nickel-cadmium, nickel-metal hydride, alkaline and lithium-ion batteries are the rechargeable types of batteries which are used in industrial applications. A rechargeable or secondary 
battery is a battery which can be charged and reused even after it has lost all or some of its charge. The battery works by accumulating and storing energy by taking advantage of a reversible electrochemical reaction [34]. This reaction occurs between a different combination of electrolytes and electrode materials and results in the flow of electrons in the battery. Table 1 shows the rechargeable battery types with their descriptions and uses [35].

Table 1. Secondary battery types including their materials and usages.

\begin{tabular}{|c|c|c|c|}
\hline Battery Type & Description & Material & Uses \\
\hline $\begin{array}{l}\text { Nickel-Cadmium } \\
\text { (NiCd) }\end{array}$ & $\begin{array}{l}\text { Popular recharge battery and least } \\
\text { expensive of rechargeable. Look for } \\
\text { recycle logo or words "battery must } \\
\text { be recycled or disposed” }\end{array}$ & $\begin{array}{l}\text { Nickel, cadmium, } \\
\text { potassium } \\
\text { hydroxide }\end{array}$ & $\begin{array}{l}\text { Power tools, cordless } \\
\text { phones, professional } \\
\text { radios }\end{array}$ \\
\hline $\begin{array}{l}\text { Nickel Metal } \\
\text { Hydride (NiMH) }\end{array}$ & $\begin{array}{l}\text { Cadmium-free replacement for } \\
\text { NiCd, more expensive but } \\
\text { considered to be less toxic. Look } \\
\text { like NiCd batteries. }\end{array}$ & $\begin{array}{l}\text { Nickel, potassium } \\
\text { hydroxide. }\end{array}$ & $\begin{array}{l}\text { Electric vehicles, power } \\
\text { tools, cordless } \\
\text { phones, professional } \\
\text { radios }\end{array}$ \\
\hline $\begin{array}{l}\text { Lithium-Ion } \\
\text { (Li-Ion) }\end{array}$ & $\begin{array}{l}\text { Expensive. Varied-shapes, depends } \\
\text { on use. High power and energy } \\
\text { density. }\end{array}$ & $\begin{array}{l}\text { Copper, aluminium, } \\
\text { carbon anode, various } \\
\text { cathode materials such } \\
\text { as LTO LCO and LFP }\end{array}$ & $\begin{array}{l}\text { Electric vehicles, } \\
\text { computers, cellular } \\
\text { phones, laptop } \\
\text { computers, digital } \\
\text { cameras }\end{array}$ \\
\hline $\begin{array}{l}\text { Rechargeable } \\
\text { Alkaline }\end{array}$ & $\begin{array}{l}\text { Moderate performance compared } \\
\text { with Ni-Cad, but costs less and } \\
\text { relatively non-toxic. Looks like } \\
\text { regular } \\
\text { alkaline batteries }\end{array}$ & $\begin{array}{l}\text { Zinc, manganese } \\
\text { dioxide, potassium } \\
\text { hydroxide }\end{array}$ & $\begin{array}{l}\text { Same uses as normal } \\
\text { alkaline and carbon-zinc } \\
\text { batteries. }\end{array}$ \\
\hline Lead-acid & $\begin{array}{l}\text { Lead acid batteries are a common } \\
\text { battery found in many vehicles to } \\
\text { provide power for engine starting. }\end{array}$ & Lead, sulphuric acid & $\begin{array}{l}\text { Car batteries, alarm } \\
\text { systems, emergency } \\
\text { lighting. }\end{array}$ \\
\hline
\end{tabular}

As seen from the tables shown above, each battery is made of a different material and is used for a different purpose. 


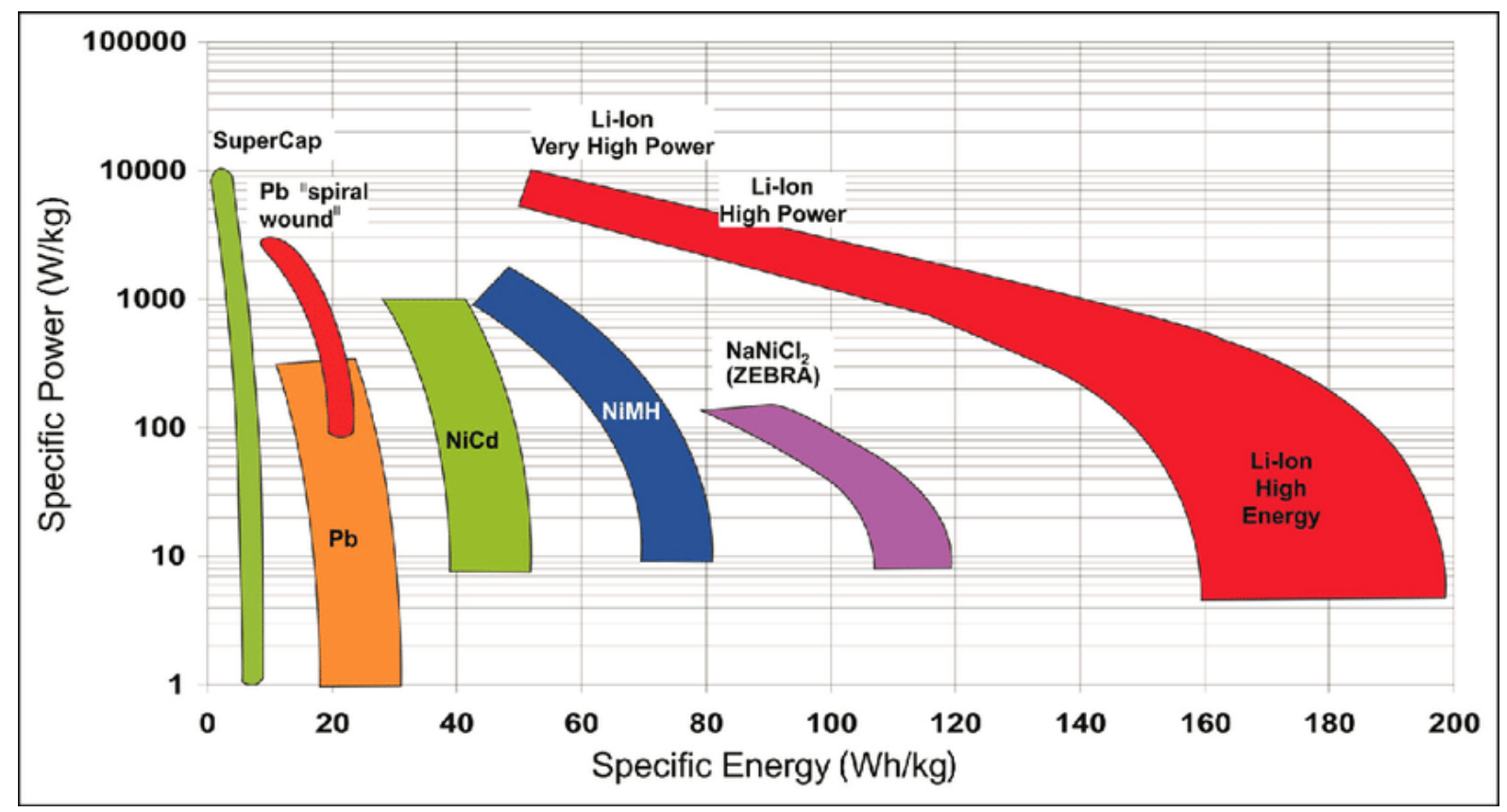

Figure 3. Ragone Plot of battery energy vs power [36].

Figure 3 shows the relative characteristics of each battery type in terms of its power and energy density. Use of the Ragone plot for the cell level specification gives an idea of how batteries can be selected for a given industrial application.

As can be seen from Figure 3, Li-ion batteries offer the highest amount of Specific Energy at nearly 200 $\mathrm{Wh} / \mathrm{kg}$ and the highest Specific Power at almost $10000 \mathrm{~W} / \mathrm{kg}$. This is then followed by NiMH and NiCd batteries which propose Specific Power of 2000 - 1000 W/kg with Specific Energy of approximately $80-50 \mathrm{Wh} / \mathrm{kg}$. Having said that, $\mathrm{NaNiCl}_{2}$ batteries deliver a higher Specific Energy at almost 120 $\mathrm{Wh} / \mathrm{kg}$, but, have the lowest Specific Power at a sum of nearly $150 \mathrm{~W} / \mathrm{kg}$. Lead-acid or Pb batteries on the other hand offer Specific Power at around $200 \mathrm{~W} / \mathrm{kg}$ and the lowest amount of Specific Energy at almost $30 \mathrm{Wh} / \mathrm{kg}$.

\subsection{Lead-Acid Batteries}

As can be guessed from the name, lead-acid batteries employ lead as the conductor and an aqueous acid solution as the electrolyte. As Dinis et al. [37] explains, the cell of the battery compromises two lead plates as electrodes that are immersed in a water solution with sulphuric acid. The battery is suggested to be the oldest type of battery and is used in many applications such as starting automobiles, powering electric trucks, delivering back-up and emergency power and several other purposes [37-40]. As Buchmann [31], and Hariprakash et al. [32] describe, the main component of the battery which is lead, is mainly associated with zinc, copper and silver and has the highest recycling rate of all materials in the world. The electrolyte, or the battery acid, is sulphuric acid that has been diluted with water to a 30$40 \%$ level of concentration depending on the battery type [41]. Sulphuric acid is described to be extremely corrosive and toxic [42]. 
Lead-acid batteries are inexpensive when compared to other types of batteries. The battery usually consists of two sets of three 2-volts single cells or one set of six 2-volts single cells that are connected in series [43]. The battery does not generate electricity on its own and only functions by storing electrical energy in terms of ions in the battery cells [44]. This means that lead-acid batteries require charging through an external source before they can be used.

As Lawson [45] explains, lead-acid batteries tend to generate heat during charge and discharge. This results in an internal temperature rise and capacity increase of the battery by $1 \% /{ }^{\circ} \mathrm{C}$. Diemand [46] notes if the internal battery temperature falls below the specific operating temperature of the battery, degradation and damage of components and materials in the battery can be caused. As McKinney et al. [47] investigates, in lead-acid batteries an internal temperature in excess of $50^{\circ} \mathrm{C}$ can accelerate the corrosion and reduce the capacity of the battery. The charge and discharge temperature range of leadacid batteries are found to be in the range of $-20^{\circ} \mathrm{C}$ to $50^{\circ} \mathrm{C}$ [44].

\subsection{Nickel-Cadmium (NiCd) Batteries}

Nickel-cadmium batteries employ an alkaline chemistry composite to provide an energy density almost double of lead-acid batteries. The battery uses nickel hydroxide $\left[\mathrm{Ni}(\mathrm{OH})_{2}\right]$ as the cathode, cadmium (Cd) as the anode, and an alkaline hydroxide solution in the form of potassium-hydroxide (KOH) as the electrolyte [48]. This has provided the battery with the opportunity to be produced in small sizes and at the same time have a high capacity rate. The cost of manufacturing these batteries has also been shown to be very low [49]. These features have made the battery particularly desirable for portable and consumer applications where weight and price are of interest. Nevertheless, other explored advantages for the nickel-cadmium batteries include high rate of charge and discharge, high operating temperature, a high number of operating life cycle, rapid charging capabilities, high coulombic efficiency, and low internal resistance [50].

A major drawback of this type of battery is having a susceptibility to memory effect, which means that the battery needs to be discharged completely before it can be recharged again [51]. Nevertheless, factors such as having low cell voltage, having expensive constituent materials due to the high cost of cadmium, and being environmentally unfriendly due to the materials used to fabricate the battery are other disadvantages with this battery type [52].

\subsection{Nickel-Metal Hydride (NiMH) Batteries}

Nickel-metal hydride batteries are a substitution for nickel-cadmium batteries. This battery uses the same composites that are used for nickel-cadmium batteries but employs hydrogen instead of cadmium as the anode [13]. The anode in this battery is made from a metal hydride such as lanthanum and actinide alloys that can be used as a solid component, which incorporates reduced hydrogen and can be oxidised to form positive charge. The electrolyte used in this type of battery is made of potassium hydroxide, which produces cells that can typically supply 1.2 Volts. The energy capacity of NiMH batteries are typically double of lead-acid batteries and NiCd batteries [53]. These batteries enable higher charge and 
discharge rates. However, much like nickel-cadmium batteries are prone to memory effect. One advantage of this cell type over a nickel-cadmium battery is that the materials used in manufacturing are considered to be more environmentally friendly [54]. Nevertheless, these batteries are still found to be more expensive than lead-acid and nickel-cadmium types.

This type of battery has previously been used in automotive applications where safety and high life cycle is of interest. The operating temperature of the battery has also explored to be extended in a wide range and between $-30^{\circ} \mathrm{C}$ to $65^{\circ} \mathrm{C}$, which also makes them very applicable for automotive use [55]. Having mentioned that and as explained by Brian Mok [56], NiMH are no longer a common technology for automotive use due to the lower energy and power density when compared to Li-Ion.

NiMH batteries typically have a high rate of self-discharge, suffer from memory effects but to a lesser extent than NiCd and the cycle life can deteriorate over time. The cell voltage of NiMH is typically around $1.2 \mathrm{~V}$ meaning more cells are required to make up a large-scale battery. Other limitations of its application are the requirement for safety vents in case of excessive gas generation and a low actual coulombic efficiency and discharge rate if charged fast [57].

\subsection{Alkaline Batteries}

Alkaline batteries are investigated to be the most popular battery types used for general applications as shown in Table 2. In this battery, an electrochemical reaction occurs between a metal and oxygen and free electrons are generated [58]. Alkaline batteries are usually as the primary type, however, new rechargeable alkaline manganese batteries also known as (RAM) have been developed which offer the same benefits as the primary type but they can be recharged [59]. These batteries incorporate potassium hydroxide (KOH) as the electrolyte, zinc as the anode and manganese dioxide as the cathode [60]. This combination makes the alkaline batteries not suffer from memory effect, unlike the nickel based batteries. The battery also offers four times more size capacity when compared to nickel based batteries and is very suitable for applications when a high drain rate is required [61]. The battery, on the other hand, is made out of non-toxic materials and is investigated to be suitable for a wide range of applications as they come in a wide range of sizes [62]. Having said that, it is discovered that the RAM cells have a very limited life-cycle and can be expensive to manufacture [63].

\subsection{Lithium-Ion Batteries}

As can be suggested, this battery contains a combination of lithium compounds as the main component. Lithium is investigated to be the lightest of metals, which has the best electrochemical properties between all the reactive metals. This enables batteries such as lithium-ion batteries to potentially have the greatest energy to power ratio, makes it suitable for heavy use and standby power applications [64]. Several different types of lithium-ion batteries have been made, each with different properties and for different applications.

The lithium-ion battery typically uses carbon as the anode, employs lithium compound such as LiMnO (LMO), LiFePO (LFP), LiTO (LTO), LiCO (LCO), LiNiMNCoO (NMC) as the cathode. It is 
discovered that these varieties of cathode material formulation give the cell its characteristics. Much development is ongoing in this field since a major breakthrough in 1990 by Dahn et al. [65] who achieved successful intercalation and de-intercalation of lithium ions using a graphite-based anode material and solvent electrolyte mixture [64-66].

This combination of chemical products makes the lithium-ion battery great to provide high energy density. This makes the battery a suitable choice for portable equipment and applications where weight and size are of paramount importance [67].

The compact size and high energy density of this battery type increases the need for a more complicated safety system to control the thermal profile of the cells. This results in a more complex battery system overall and this can increase manufacturing costs. However, the continuous improvement of li-ion polymer-based separators over recent years have mitigated many of the safety concerns in this respect. As the volume of manufacture for this battery type has increased, the cost of production has reduced dramatically making li-ion a common choice for automotive and energy storage applications [68].

Lithium-ion batteries have many attractive advantages over other industrial battery types and chemistries are available which cater for high power and high energy applications. When compared with the aforementioned battery types, li-ion cells offer a range of benefits including high cell voltage, low self-discharge, high cycle life and lower internal resistance and a high coulombic efficiency, often above $99 \%$ in beginning of life cells [69].

In order to protect these desirable characteristics, the battery requires a method for preventing overcharge, overdischarge and maintaining temperature conditions within specific limits. Typically, this is achieved through the use of a battery management system. Without this, li-ion batteries suffer from a plethora of degradation mechanisms which ultimately results in capacity or power fade. At elevated temperatures a li-ion battery, depending on its exact chemistry, can suffer from growth or decomposition of a layer known as the solid electrolyte interphase, or interface in some literature. Damage can also occur to the electrolyte within the cell and to the binder agent which attaches the anode and cathode materials to the copper and aluminium current collectors [69-70]. Nonetheless, the battery can also become inefficient and unreliable when it is low in charge or operated at low temperatures.

\section{Thermal Management}

As shown in Figure 4, the performance of a battery can change drastically with temperature [71-73]. As can be seen, the capacity of the battery drastically decreases as the operating temperature decreases and vice versa. However, at elevate temperatures a reduction in cycle life is witnessed in most battery types. As Jaguemont et al. [74] explains, this is mainly caused as the extremely low temperature can freeze the battery and cause reduction of capacity whilst higher extreme temperatures can destroy the active chemical components in the battery. The cell temperature performance, however, improves when the temperature of the battery is kept between limits as shown in Table 2 . 


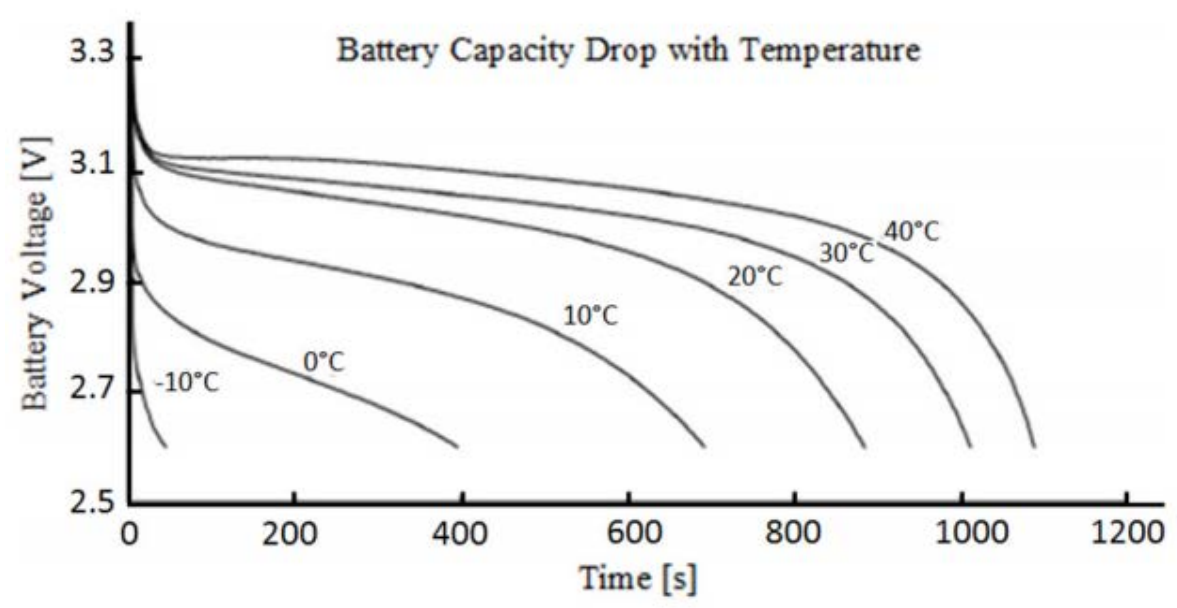

Figure 4. Performance of a battery with Temperature [73].

Table 2: Operating Temperature of Battery Types used for Industrial Applications.

\begin{tabular}{|c|c|c|c|}
\hline Reference & Type of Battery & Charging Temperature & Discharging Temperature \\
\hline \multirow{3}{*}[75]{} & Lead acid & $-20^{\circ} \mathrm{C}$ to $50^{\circ} \mathrm{C}$ & $-20^{\circ} \mathrm{C}$ to $50^{\circ} \mathrm{C}$ \\
\cline { 2 - 4 } & NiCd,NiMH & $0^{\circ} \mathrm{C}$ to $45^{\circ} \mathrm{C}$ & $-20^{\circ} \mathrm{C}$ to $65^{\circ} \mathrm{C}$ \\
\cline { 2 - 4 } & Li-ion & $0^{\circ} \mathrm{C}$ to $45^{\circ} \mathrm{C}$ & $-20^{\circ} \mathrm{C}$ to $60^{\circ} \mathrm{C}$ \\
\hline
\end{tabular}

As it is investigated so far, all batteries function based on an electrochemical process and as shown above, the operating performance of batteries depends largely on temperature. As Wang et al. [76] discovers, the internal chemical reaction which occurs inside a battery is activated either by temperature or voltage difference. In simple terms, the hotter the battery gets, the quicker the electrochemical process takes place, up until to a certain temperature. Saw et al. [77] further explains that the rise in heat will also result in the increase of unwanted side reactions within the battery which cause loss of battery capacity and a bigger self-discharge rate. As aforementioned, depending on the battery type, the rise of battery temperature can result in corrosion, passivation on the anode and cathode electrodes, gassing and ultimately as a result for all battery types, reduction in cycle life. In conclusion, it can be explained that temperature has several adverse effects, both on the cycle life and performance of a battery, due to the electrochemical reaction of the battery. This is further explained by the Arrhenius equation shown below, which defines the relationship between the rate of electrochemical reaction and temperature [78].

$$
k=A e^{-E / R T}
$$

Where $k$ is the rate at which electrochemical reaction takes place, $A$ is a constant factor related to the frequency of molecules collision over a temperature range, e is the Euler's number, $E$ or the activation energy is a constant which represents the minimum energy required to initiate the reaction, $\mathrm{R}$ is the Universal Gas Constant, and $\mathrm{T}$ is the temperature in Kelvin. 
The above equation shows that the rate at which the reaction takes place rises rapidly as the temperature increases. It is explained that in general, a rise in temperature of approximately $10^{\circ} \mathrm{C}$, increases the chemical reaction rate inside the battery and reduces the battery life by almost a factor of two [79]. This means that in terms of battery life, one-hour operation at $30^{\circ} \mathrm{C}$ is the same as two hours operation at $20^{\circ} \mathrm{C}$. Heat can be described as the number one enemy of batteries and as it was shown through Equation 5 , a small rise in the value of $T$ would affect the chemical reactions and a result the performance of the battery by a large sum.

This is also apparent in Figure 5 where it is clear that the life of a typical lead-acid battery is shortened by almost 27 years when it is operated at high temperatures. This shows that if the battery temperature could be kept at for instance $15^{\circ} \mathrm{C}$, the life of the battery could be extended and the battery would retain just below 95\% of its original capacity for a significantly longer period of time [80].

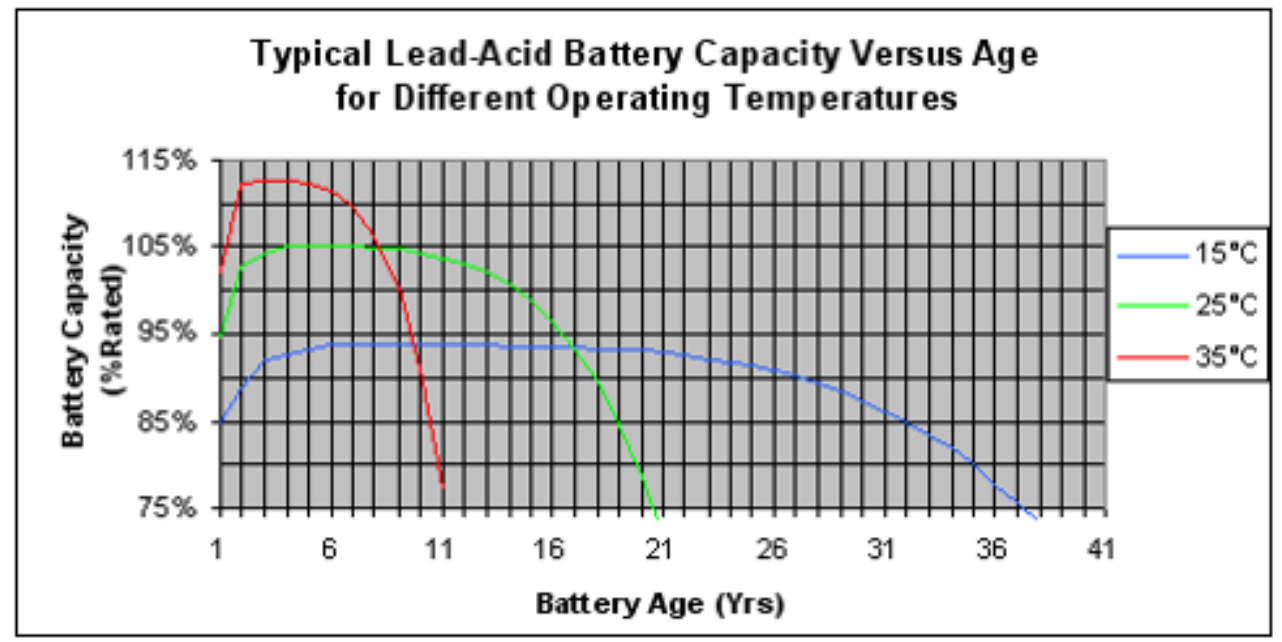

Figure 5. Typical Lead-Acid Battery Capacity vs Age at Different Operating Temperature [80].

Other examples of where the temperature could directly affect the performance and age of a battery is the case of the nickel-metal hydride electrochemistry where a constant exposure to a temperature of $45^{\circ} \mathrm{C}$ increases the self-discharge rate and brings the battery life down by almost $60 \%$ [81]. Apart from this, the steady degradation of the battery over time, overheating of the cells under certain conditions can result in damaging of the cell. This condition can also occur under normal operation of the battery where the heat loss from the battery exceeds the safe operating temperature of the cell, causing extreme thermal runaway and ultimately the destruction of the battery [16].

The conclusion is that the rapid increase of the cell temperature during charging and discharging can affect the battery in many defective ways. The high temperature of the battery can initiate undesirable and adverse electrochemical reactions that can result in failure of the battery. This, therefore, indicates that if the batteries are thermally controlled and maintained, more life and capacity and power can be obtained and their performance can be optimised.

There are a number of ways in which performance can be optimised and safety maintained within a battery pack. Figure 6 shows a system level architecture of how battery packs can be thermally 
managed. The exact temperature at which these controls are managed may be unique to each battery pack configuration.

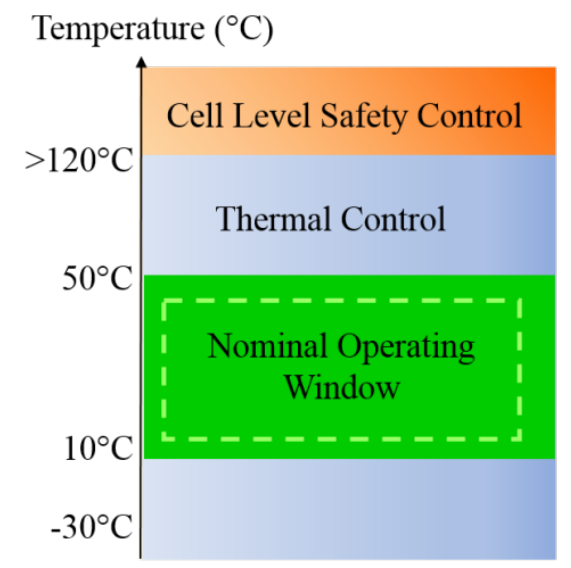

Figure 6. Thermal management architecture within an industrial battery pack.

The most basic of thermal controls is a cell level safety control. For instance, in a lithium-ion battery the first level of protection is an intrinsic safety device built into most commercial cells. These typically feature thermal safety controls such as a current interupt device (CID), a positive thermal coefficient (PTC) current limiting switch and a burst pressure disc to release excessive internal pressure as a failsafe for other thermal controls not operating correctly [82].

Beyond these failsafes, modern battery packs are equipped with complex system level thermal management systems which control the level of available current based on the temperature of the cells. That is to say that the current is reduced when the temperature of the cells reaches the edges of the normal temperature operating window. The result is that the system functions within the specification temperature limits. In order to facilitate this function, many battery packs are installed with protection circuits to monitor the levels of temperature within the cells.

However, even with these basic thermal management controls in place, where battery packs function without the assistance of a cooling system this does not mean that the life of the cells can be prolonged. Much tighter thermal controls of battery cells are required in order to provide this. Where large energy storage systems are created with multiple cells connected in series and parallel, the performance of the pack is determined by the most limiting cell in the pack (the highest temperature cell or the lowest available capacity). The single weakest cell cannot function outside its normal operating window and so each cell must adopt the same thermally controlled current limits. This means the performance of the whole pack is reduced as a result. It is for this reason that the homogeneity of temperature across each individual cell in a lithium-ion battery pack is a principal concern.

\subsection{Battery Thermal Management Techniques and Benefits}

As Zhoujian et al. [83] indicate, thermal management of batteries can be classified into two categories, heating and cooling. Ghadbeigi et al. [84] discover it is relatively easy to thermally manage a battery 
that is suffering from low-temperature effects. As Woodbank [85] describes, this can be simply achieved by using the internal energy of the battery to heat up the cells using controlled heating elements and bringing the battery up to the optimum operating temperature. On the other hand, other methods include keeping the battery constantly on charging and discharging cycles which will result in the continuous generation of internal temperature. This can result in a phenomenon known as lithium plating, as described by Zinth and Lüders [86], which can lead to a reduced battery lifespan and even short-circuits due to lithium dendrite growth.

Techniques that are employed to cool down batteries can be however, more complicated than the methods used for heating. These systems tend to make the use of several heat transfer principles to actively or passively take the generated heat away from batteries and by cooling them, improve their cycle life. The efficiency of a battery on the other hand and as explained before tends to increase with temperature, as the internal resistance is reduced due to higher temperatures, resulting in lower power losses and hence a higher efficiency. The main advantages offered by cooling techniques include dissipation of excessive heat, protection from overheating, uniform distribution of heat through the battery pack, and system performance improvement [87].

\subsubsection{Overheating Protection}

As mentioned before and indicated through the Arrhenius Law, for every $10^{\circ} \mathrm{C}$ internal temperature increase, the internal chemical reaction of the battery cell doubles, which in return will result in more stress to the battery and deterioration of the cells.

Protection from overheating in simple terms involves observing the temperature of a single cell or the battery pack and deciding whether the temperature level is in an acceptable range or not.

For instance, Littelfuse [88-89] designed a battery management system to thermally control and protect a Lithium-ion polymer battery from overheating by monitoring the charge and discharge conditions at the cell level. Using protection circuits as $H u$ [90] reports, will provide a shield against unexpected overheating of the battery while keeping thermal impacts to a minimum.

\subsubsection{Heat Dissipation}

As explained before, when a battery is overheated and its operating temperature limits are reached, the current flow within the battery can be reduced.. It is explained that heat flows by the mean of radiation, convection and conduction out of the battery cells and thus in order to prevent the battery pack from overheating, it should be designed in a way to naturally keep the temperature of the cells down [91]. This was demonstrated by Rohatgi [92] where a plate as heat conducting pathways was placed between each cell to allow natural air flow through the battery pack. On the other hand, $\mathrm{Na}$ [93] designed a novel contraption which incorporates rectifier grids that allows airflow between cells and manage to reduce the average temperature of the cells by almost $3^{\circ} \mathrm{C}$. Having demonstrated this, it should be noted that this method is ideal for low power batteries that do not generate much heat. 


\subsubsection{Heat Distribution}

Although the above-mentioned method could help to bring the average temperature of the battery down, as Rabczak et al. [94] reveal, localised hot spots could still be developed inside the battery pack which can violate the operating temperature limit. This, as investigated by Lu et al. [95], will largely affect the inner cells which are located in the middle of the pack with no benefit of convective cooling on their outer surfaces. In this study, it was demonstrated that in order to reduce the effect of heat conduction from the hot spot of one cell to another, the cells were separated and cool air was directed between the cells to remove the heat. In another study conducted by Lu et al. [96], air was forced through several cooling channels that were placed around the cells of a densely-packed battery box and by taking heat from the cells, the generation of hot spots was also drastically reduced.

Passive methods can also be employed, as illustrated by Jaguemon et al. [97], to dissipate heat from the cells and distribute heat throughout the battery pack without the need of any energy input to the system. For example, Huber [98] studied how the use of a phase change material (PCM) over a battery pack can absorb heat from the cells and be used that to change the state of the PCM from solid to liquid. This in return increased the potentiality of the heat flow all over the battery pack, thus equalising the temperature of the cells. Alrashdan et al. [99] successfully showed an improvement in thermal control of the battery cells in a study which employed graphite sponge, a material with high conductivity, soaked in wax as a thermal transfer medium to absorb more heat from the battery cells. One possible limitation of this approach is the availability of a PCM with a transition temperature which matches the desired operating temperature for optimisation of the battery pack cycle life.

\subsection{Techniques used for High-Performance Applications}

Thermal cooling systems for high power applications can however be different in design when compared to the methods explained above, which are normally used for low power applications. As explained by Sabbah [100], passive cooling techniques may not be sufficient enough to achieve the optimum operating temperature of the battery and active cooling may be required. One limitation of this approach is the need for additional power for this system, which adds weight, complexity and can reduce the efficiency of the system. The use of such systems should therefore be avoided if possible.

However, as demonstrated by Lee [101], a fan can be employed to blow air to the battery packs of a hybrid electric vehicle and thermally cool down the cells to the optimum operating temperature. In another study, conducted by Chen et al. [102], air flow was forced through a set of lithium-ion battery cells which were placed in a specially designed duct and by increasing the air velocity, the temperature of the battery pack was reduced. Using active forced air cooling is investigated to be a relatively simple and low-cost arrangement for thermal management of batteries [101], however it is investigated that the low and limiting heat transfer rate offered by the system make this method ineffective when dealing with high thermal applications as in high power batteries. 
Li et al. [103] nevertheless, came up with a novel air cooling technique by combining a 1.5mm double silica cooling plate with copper mesh and demonstrated that by passing air at a velocity of $3.5 \mathrm{~m} / \mathrm{s}$, the maximum temperature of a lithium ion battery pack during a 5C discharge process can be reduced by almost $10^{\circ} \mathrm{C}$. This study investigated the effectiveness of the proposed technique by monitoring the temperature of the batteries at different air velocities and different thickness of the heat absorption material.

Methods such as liquid cooling have also been used and tested which are a more common technique for high thermal application where, due to the operating temperature of the battery cells, forced air techniques cannot be used [104]. When the cooling rate that needs to be applied to the system is very high, working fluids with a high thermal capacity can be employed as a medium to transfer heat from the battery cells. For example, Patil et al. [105] in an experiment proposed a method which uses mineral oil as a coolant that is passed through channels that hold lithium-ion battery cells. It was determined this technique can reduce the average temperature of the cells and provide a temperature uniformity below $1^{\circ} \mathrm{C}$ for the battery pack, which will result in an extension of lifetime and durability of the battery. Shang et al. [106] on the other hand, proposed a liquid cooling system by designing a series of heat absorption plates that can be used for surface cooling of lithium-ion battery packs. As can be seen from Figure 7, the cooling plates are in direct touch with the surface of the battery packs. In this design, as the temperature of the batteries increases, the coolant that can be a mixture of glycol and water is pumped through the cooling plates to absorb and take the heat away from the battery packs. In this study and through an experiment, it was demonstrated that with the use of this technique, the temperature of the battery packs could be kept at below $35^{\circ} \mathrm{C}$, which is an ideal operating temperature for lithium-ion batteries.

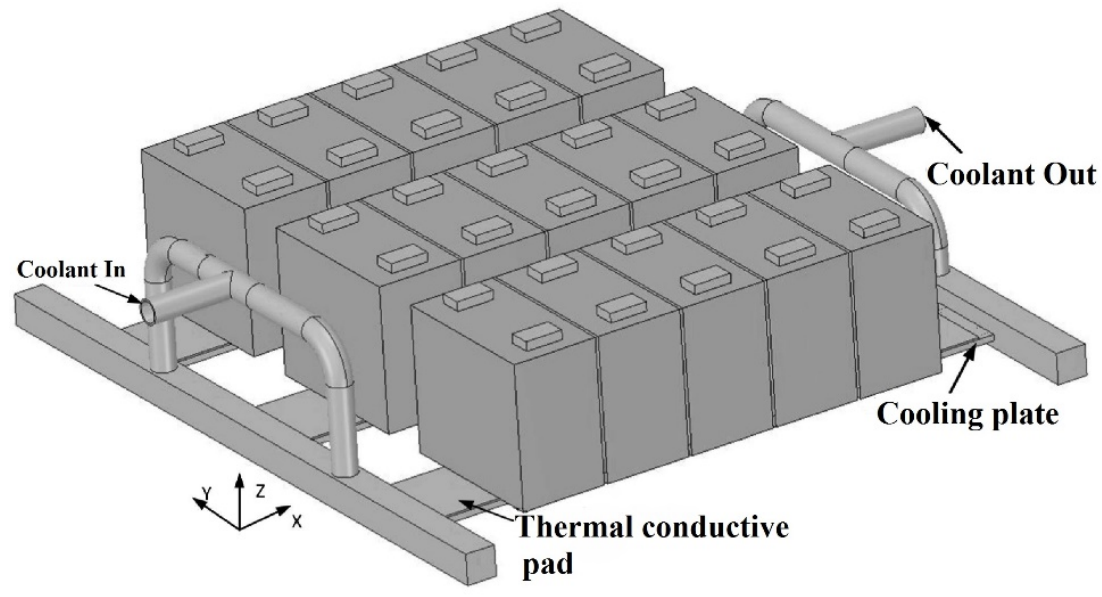

Figure 7. Battery pack cooling system incorporating liquid cooling plates by Shang et al. [106].

Other techniques are also available which incorporate heat recovery methods and can be used to improve the overall efficiency of the cooling system. In simple terms, these systems can be integrated with the vehicle climate control system to take heat from the battery pack and transfer that to, or from, the passenger compartment or be used to generate electricity. This for example, was shown by Ohno et 
al. [107] where $30 \%$ of the energy required for a vehicle cabin heating was recovered from the battery pack of an electric vehicle through a plate heat exchanger.

It should be indicated that such a system can be useful during cold weather operation but may have a limited usage when the ambient temperature is high. This process can also be applied to thermally manage and cool down the battery pack. For instance as demonstated by Toyota [108], cabin air temperature of a Toyota Prius is controlled by the main air conditioning system of the vehicle and then passes around the battery pack for cooling. This air-cooling system is discovered to be more efficient than similar air-cooling types and the battery is investigated to have a greater energy regeneration range [109].

In another experiment conducted by Al-Zareer et al. [110], a battery cooling system was proposed which incorporates aluminium cold plates that are filled with liquid ammonia and are placed around the battery pack as shown in Figure 8. It was demonstrated that the heat from the battery pack vaporises the ammonia while cooling the plate and therefore the battery pack. The vapour ammonia was then diverted to an electrical generator where electricity is produced to charge the batteries. The proposed design in this experiment managed to maintain the maximum temperature of the battery pack below $25^{\circ} \mathrm{C}$ with a temperature uniformity of less than $3^{\circ} \mathrm{C}$.

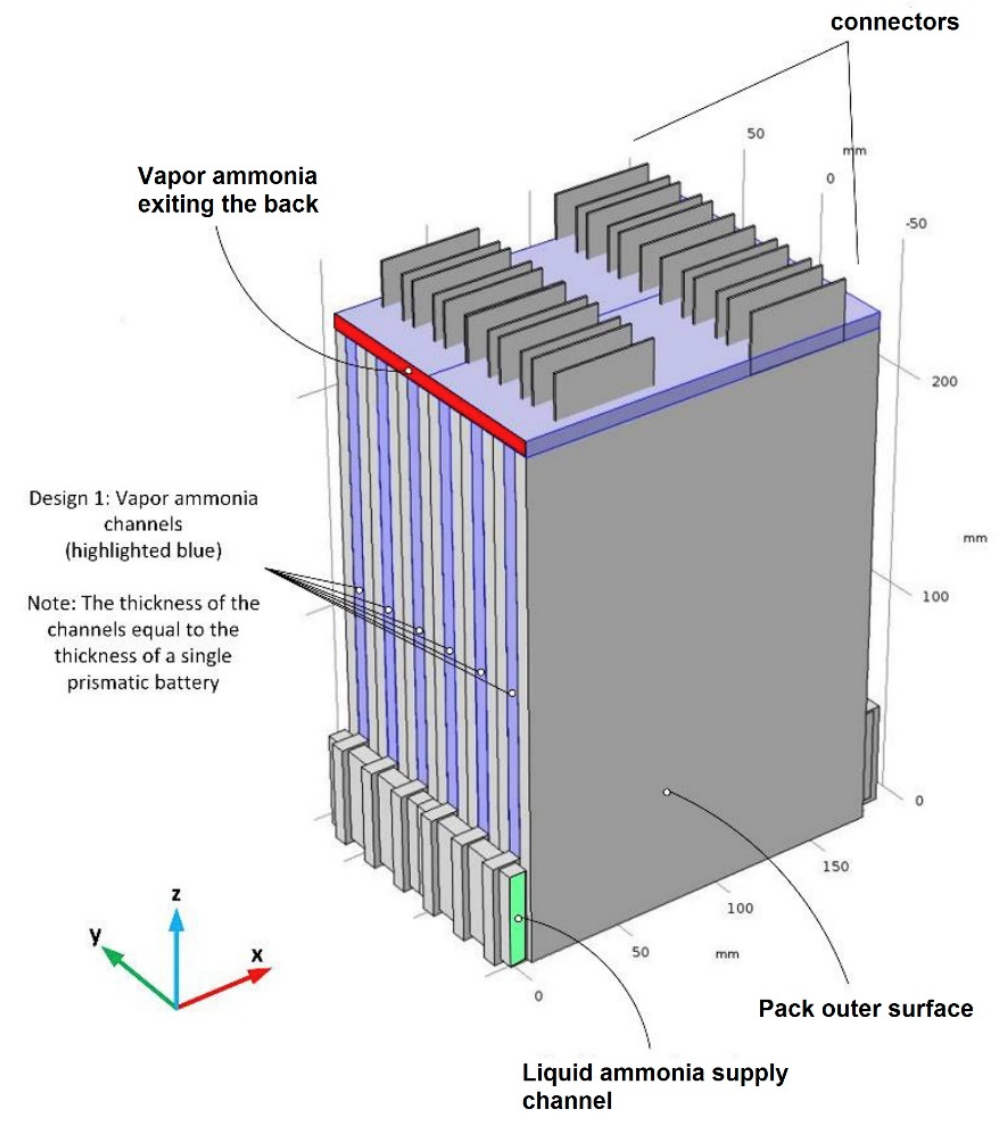

Figure 8. Battery pack cooling system designed by Al-Zareer et al. [110].

Bambang et al. [111] in an experiment placed a flat plate loop heat pipe on a battery pack of an electric vehicle and that resulted in uniformly and effectively taking the heat away from the cells and reducing 
the temperature. In this experiment acetone used as the working fluid in the heat pipe, producing a thermal resistance of $0.22^{\circ} \mathrm{C} / \mathrm{W}$ with $50^{\circ} \mathrm{C}$ evaporator temperature at heat flux load of $1.6 \mathrm{~W} / \mathrm{cm} 2$.

In another experiment, as can be seen from Figure 9, Smith et al. [112] proposed and fabricated a heat pipe based thermal management system for a high power battery and proved that the system can successfully dissipate $50 \mathrm{~W}$ of heat load from each cell of the battery. The results from these experiments indicated that the recovered heat could then be used to improve the overall efficiency of the system. It is also concluded that using heat pipes for thermal management systems can be a very effective and simple option for high-performance applications.

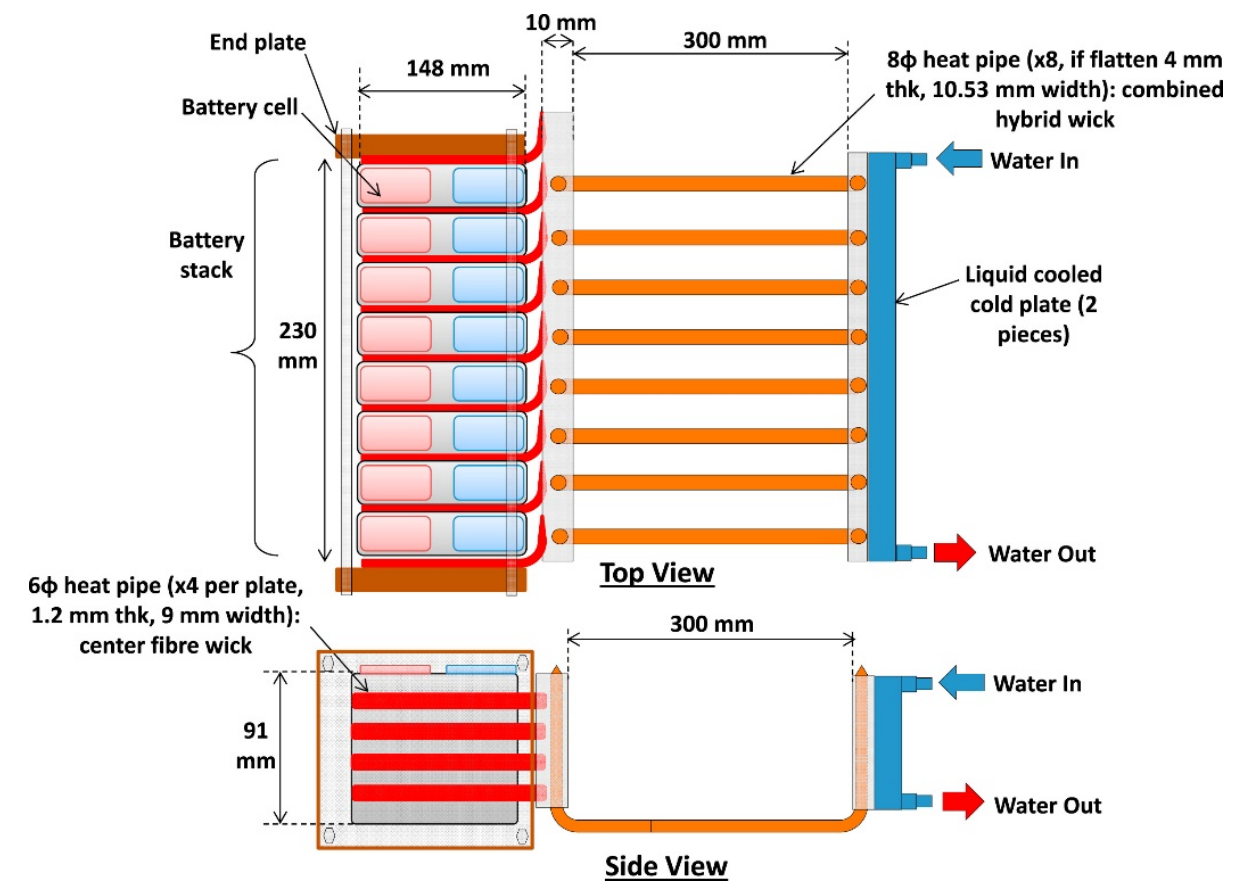

Figure 9. Battery pack cooling system incorporating heat pipes by Smith et al. [112].

\section{Discussion and Recommendation}

So far, it is investigated that different thermal management techniques can be applied to different thermal related issues of a battery to enable performance and efficiency improvements. To explain this further, Xia et al. [113] investigates that parameters such as temperature range and variation affect a battery pack at cell and module level. Therefore, in order to provide a suitable thermal management solution, the way the heat is generated, transported and dissipated must be looked at. Furthermore, a different thermal management strategy means a different overall performance and parameters such as average temperature gradient of the battery must in particular be considered as an important factor.

On the other hand, in every instance and in order to get the most optimum thermal management performance, the configuration of the system must be carefully designed. This means that parameters which affect the battery pack as the result of thermal related issues must be studied and based on that an optimum thermal management system or boundaries must be designed and configured. The table 
shown below indicates several different studies and include the thermal management method applied for different battery types with the results achieved.

Table 3: Thermal Management Methods and Conclusion

\begin{tabular}{|c|c|c|c|c|}
\hline Reference & Description & $\begin{array}{c}\text { Thermal } \\
\text { Management } \\
\text { Configuration }\end{array}$ & Results & Conclusion \\
\hline [114] & $\begin{array}{l}\text { Thermal } \\
\text { management of } \\
\text { batteries } \\
\text { employing } \\
\text { active } \\
\text { temperature } \\
\text { control and } \\
\text { reciprocating } \\
\text { cooling flow. }\end{array}$ & $\begin{array}{l}\text { An active } \\
\text { temperature control } \\
\text { and a reciprocating } \\
\text { cooling flow was } \\
\text { employed which } \\
\text { delivered cool air } \\
\text { through a cooling } \\
\text { fan around several } \\
\text { battery cells placed } \\
\text { in series. Based on } \\
\text { this, the core } \\
\text { temperature of the } \\
\text { cells were } \\
\text { monitored and } \\
\text { controlled. }\end{array}$ & $\begin{array}{l}\text { Comparing results } \\
\text { with unidirectional } \\
\text { control flow } \\
\text { indicated that } \\
\text { temperature non- } \\
\text { uniformity was } \\
\text { reduced from } 4.2 \text { to } \\
1^{\circ} \mathrm{C} \text {. }\end{array}$ & $\begin{array}{l}\text { The results suggested } \\
\text { that the control } \\
\text { method when } \\
\text { combined with } \\
\text { reciprocating cooling } \\
\text { flows, reduces both } \\
\text { the cells temperature } \\
\text { and temperature non- } \\
\text { uniformity. }\end{array}$ \\
\hline [115] & $\begin{array}{l}\text { Thermal } \\
\text { management of } \\
\text { a Li-ion battery } \\
\text { pack employing } \\
\text { water } \\
\text { evaporation. }\end{array}$ & $\begin{array}{l}\text { A novel method of } \\
\text { thermal } \\
\text { management was } \\
\text { introduced which } \\
\text { employed water } \\
\text { evaporation } \\
\text { techniques. This } \\
\text { was conducted by } \\
\text { applying a thin } \\
\text { sodium alginate } \\
\text { film with water } \\
\text { contact of } 99 \text { wt\% } \\
\text { directly to the } \\
\text { surface of a battery } \\
\text { pack. }\end{array}$ & $\begin{array}{l}\text { The result indicated } \\
\text { that under the } \\
\text { condition with } \\
\text { constant charging } \\
\text { and discharging } \\
\text { larger than } 1 \mathrm{C} \text {, the } \\
\text { temperature rise } \\
\text { rate can be reduced } \\
\text { by almost half. }\end{array}$ & $\begin{array}{l}\text { The proposed } \\
\text { method indicated to } \\
\text { be a very efficient } \\
\text { and convenient } \\
\text { method of tackling } \\
\text { the thermal surge of } \\
\text { a battery pack } \\
\text { without the need of } \\
\text { making any changes } \\
\text { to the battery pack } \\
\text { assembly. }\end{array}$ \\
\hline
\end{tabular}




\begin{tabular}{|c|c|c|c|c|}
\hline [116] & $\begin{array}{l}\text { Novel thermal } \\
\text { management } \\
\text { system using } \\
\text { boiling cooling } \\
\text { for high- } \\
\text { powered } \\
\text { lithium-ion } \\
\text { battery packs for } \\
\text { hybrid electric } \\
\text { vehicles. }\end{array}$ & $\begin{array}{l}\text { A new method of } \\
\text { thermal } \\
\text { management based } \\
\text { on Phase Change } \\
\text { Material (PCM) } \\
\text { was developed. In } \\
\text { this system, the } \\
\text { battery cells were } \\
\text { placed in a liquid } \\
\text { propane medium, } \\
\text { which when heats } \\
\text { up will boil and } \\
\text { removes the } \\
\text { generated heat } \\
\text { away from the } \\
\text { batteries. }\end{array}$ & $\begin{array}{l}\text { The results } \\
\text { indicated that the } \\
\text { propane based } \\
\text { PCM thermal } \\
\text { management } \\
\text { system can } \\
\text { maintain the } \\
\text { temperature of the } \\
\text { batteries below } \\
34^{\circ} \mathrm{C} \text { under high } \\
\text { continuous charge } \\
\text { and discharge } \\
\text { cycles at } 7.5 \mathrm{C} \text {. }\end{array}$ & $\begin{array}{l}\text { This method of } \\
\text { thermal management } \\
\text { was concluded to } \\
\text { provide good cooling } \\
\text { performance in terms } \\
\text { of reducing } \\
\text { maximum } \\
\text { temperature of the } \\
\text { batteries and } \\
\text { delivering } \\
\text { temperature } \\
\text { uniformity through } \\
\text { the battery cells. }\end{array}$ \\
\hline [117] & $\begin{array}{l}\text { Thermal } \\
\text { management for } \\
\text { high power } \\
\text { lithium-ion } \\
\text { battery by } \\
\text { minichannel } \\
\text { aluminium } \\
\text { tubes. }\end{array}$ & $\begin{array}{l}\text { A novel technique } \\
\text { of battery thermal } \\
\text { management was } \\
\text { developed based on } \\
\text { aluminium mini- } \\
\text { channel tubes, } \\
\text { which are placed } \\
\text { around a battery } \\
\text { pack. }\end{array}$ & $\begin{array}{l}\text { Through this } \\
\text { method, it was } \\
\text { discovered that the } \\
\text { maximum cell } \\
\text { temperature can be } \\
\text { kept less than } \\
27.8^{\circ} \mathrm{C} \text { with almost } \\
0.8^{\circ} \mathrm{C} \text { temperature } \\
\text { uniformity. }\end{array}$ & $\begin{array}{l}\text { The reduced } \\
\text { temperature and very } \\
\text { low value of uniform } \\
\text { temperature } \\
\text { distribution inside } \\
\text { the cells indicated } \\
\text { that this method can } \\
\text { provide a promising } \\
\text { solution as a thermal } \\
\text { management system. }\end{array}$ \\
\hline [118] & $\begin{array}{l}\text { Heat transfer } \\
\text { and thermal } \\
\text { management } \\
\text { with PCMs in a } \\
\text { Li-ion battery } \\
\text { cell for electric } \\
\text { vehicles. }\end{array}$ & $\begin{array}{l}\text { In this study, a } \\
\text { passive thermal } \\
\text { management } \\
\text { method was } \\
\text { developed by } \\
\text { applying phase } \\
\text { change materials } \\
\text { with different } \\
\text { thickness around } \\
\text { the cells. }\end{array}$ & $\begin{array}{l}\text { The results } \\
\text { indicated that by } \\
\text { employing the } \\
\text { PCM materials } \\
\text { with thickness of } \\
3 \mathrm{~mm} \text {, the } \\
\text { temperature of the } \\
\text { cells can be } \\
\text { reduced by } 2.8^{\circ} \mathrm{C} \\
\text { and the temperature } \\
\text { uniformity can be }\end{array}$ & $\begin{array}{l}\text { It was concluded that } \\
\text { using PCMs for } \\
\text { thermal management } \\
\text { can reduce the } \\
\text { maximum } \\
\text { temperature and } \\
\text { temperature } \\
\text { excursion in the } \\
\text { cells. }\end{array}$ \\
\hline
\end{tabular}




\begin{tabular}{|c|c|c|c|c|}
\hline & & & $\begin{array}{l}\text { increased by almost } \\
10 \% .\end{array}$ & \\
\hline [119] & $\begin{array}{l}\text { Experimental } \\
\text { investigation on } \\
\text { thermal } \\
\text { management of } \\
\text { electric vehicle } \\
\text { battery with heat } \\
\text { pipe. }\end{array}$ & $\begin{array}{l}\text { A heat pipe based } \\
\text { thermal } \\
\text { management } \\
\text { method was } \\
\text { designed to achieve } \\
\text { optimum } \\
\text { temperature range } \\
\text { and even } \\
\text { temperature } \\
\text { distribution for a } \\
\text { battery pack. }\end{array}$ & $\begin{array}{l}\text { The experimental } \\
\text { results showed that } \\
\text { when the generated } \\
\text { heat is around } \\
50 \mathrm{~W} \text {, the maximum } \\
\text { temperature can be } \\
\text { controlled below } \\
50^{\circ} \mathrm{C} \text {, keeping the } \\
\text { temperature } \\
\text { uniformity at just } \\
\text { below } 5^{\circ} \mathrm{C} \text {. }\end{array}$ & $\begin{array}{l}\text { It was demonstrated } \\
\text { that using heat pipes } \\
\text { based thermal } \\
\text { management } \\
\text { techniques can be an } \\
\text { effective way of } \\
\text { controlling and } \\
\text { dealing with batteries } \\
\text { that dissipate high } \\
\text { amount of heat. }\end{array}$ \\
\hline [120] & $\begin{array}{l}\text { Optimization of } \\
\text { the passive } \\
\text { thermal control } \\
\text { system of a } \\
\text { lithium-ion } \\
\text { battery with heat } \\
\text { pipes embedded } \\
\text { in an aluminium } \\
\text { plate. }\end{array}$ & $\begin{array}{l}\text { A thermal } \\
\text { management } \\
\text { technique for high- } \\
\text { power batteries is } \\
\text { configured. The } \\
\text { design incorporates } \\
\text { metal plates and } \\
\text { heat pipes which } \\
\text { are attached } \\
\text { directly to the } \\
\text { battery cells in a } \\
\text { sandwich } \\
\text { configuration. }\end{array}$ & $\begin{array}{l}\text { By using } 1-5 \\
\text { number of heat } \\
\text { pipes in a loop } \\
\text { configuration on } \\
\text { the surface of the } \\
\text { plate, the maximum } \\
\text { temperature of the } \\
\text { cells were reduced } \\
\text { by nearly } 10-12^{\circ} \mathrm{C} \text {, } \\
\text { while keeping the } \\
\text { temperature } \\
\text { uniformity to } \\
\text { almost } 2-3^{\circ} \mathrm{C} \text {. }\end{array}$ & $\begin{array}{l}\text { It was concluded that } \\
\text { the plate and heat } \\
\text { pipe based system } \\
\text { decreases the } \\
\text { maximum } \\
\text { temperature of the } \\
\text { cells, however, it } \\
\text { also increased the } \\
\text { total price and } \\
\text { complexity of the } \\
\text { system. }\end{array}$ \\
\hline [121] & $\begin{array}{l}\text { Thermal } \\
\text { management of } \\
\text { Li-ion battery } \\
\text { with liquid } \\
\text { metal }\end{array}$ & $\begin{array}{l}\text { A liquid battery } \\
\text { thermal } \\
\text { management } \\
\text { method is proposed } \\
\text { that employs liquid } \\
\text { metal as coolant. } \\
\text { The coolant is fed } \\
\text { through several } \\
\text { channels that } \\
\text { incorporate a series }\end{array}$ & $\begin{array}{l}\text { It was discovered } \\
\text { that through this } \\
\text { method, the battery } \\
\text { cells temperature } \\
\text { that are being } \\
\text { discharged at a rate } \\
\text { of } 3 \mathrm{C} \text { could be } \\
\text { lowered down by } \\
\text { almost } 7^{\circ} \mathrm{C} \text {. } \\
\text { Nevertheless, in }\end{array}$ & $\begin{array}{l}\text { The excellent cooling } \\
\text { capability of using } \\
\text { liquid metal for the } \\
\text { liquid thermal } \\
\text { management of a } \\
\text { pack of li-ion battery } \\
\text { was proved. It was } \\
\text { noted that the use of } \\
\text { this coolant will also } \\
\text { bring other benefits }\end{array}$ \\
\hline
\end{tabular}




\begin{tabular}{|c|c|c|c|c|}
\hline & & $\begin{array}{l}\text { of aluminium } \\
\text { jackets, which are } \\
\text { placed between the } \\
\text { battery cells. }\end{array}$ & $\begin{array}{l}\text { comparison to other } \\
\text { coolants such as } \\
\text { water, the use of } \\
\text { liquid metal was } \\
\text { shown to reduce the } \\
\text { average cell } \\
\text { temperature by } \\
\text { nearly } 2^{\circ} \mathrm{C} \text {. }\end{array}$ & $\begin{array}{l}\text { such as the need of } \\
\text { less mass flowrate } \\
\text { and power } \\
\text { consumption. }\end{array}$ \\
\hline [122] & $\begin{array}{l}\text { A hybrid } \\
\text { thermal } \\
\text { management } \\
\text { system for } \\
\text { lithium ion } \\
\text { batteries } \\
\text { combining } \\
\text { phase change } \\
\text { materials with } \\
\text { forced-air } \\
\text { cooling }\end{array}$ & $\begin{array}{l}\text { A unique } \\
\text { configuration that } \\
\text { integrates phase } \\
\text { change materials } \\
\text { (PCM) with forced } \\
\text { air convection is } \\
\text { presented and } \\
\text { experimentally } \\
\text { analysed. In this } \\
\text { study, lithium-ion } \\
\text { battery cells were } \\
\text { surrounded by s } \\
\text { PCM composite } \\
\text { and placed into a } \\
\text { rectangular air } \\
\text { tunnel to be cooled } \\
\text { down. }\end{array}$ & $\begin{array}{l}\text { The experiment } \\
\text { included fully } \\
\text { charging and } \\
\text { discharging the } \\
\text { battery cells } \\
\text { continuously at a c- } \\
\text { rate of } 1 \mathrm{C} \text { to } 2 \mathrm{C} \\
\text { respectively. The } \\
\text { results indicated } \\
\text { that the temperature } \\
\text { of the cells can be } \\
\text { reduced by nearly } \\
10^{\circ} \mathrm{C} \text { to almost } \\
\text { below } 50^{\circ} \mathrm{C} \text {, } \\
\text { keeping the } \\
\text { temperature } \\
\text { distribution by the } \\
\text { PCM material at } \\
\text { less than } 3^{\circ} \mathrm{C} \text {. }\end{array}$ & $\begin{array}{l}\text { The proposed system } \\
\text { was shown to } \\
\text { successfully prevent } \\
\text { heat accumulation } \\
\text { and maintains the } \\
\text { maximum } \\
\text { temperature of the } \\
\text { battery cells under } \\
\text { the optimal operating } \\
\text { temperature in all } \\
\text { cycles, while } \\
\text { obtaining ideal cell } \\
\text { temperature } \\
\text { uniformity. }\end{array}$ \\
\hline [123] & $\begin{array}{l}\text { Experimental } \\
\text { investigation of } \\
\text { the thermal } \\
\text { performance of } \\
\text { heat pipe } \\
\text { assisted phase } \\
\text { change material } \\
\text { for battery } \\
\text { thermal }\end{array}$ & $\begin{array}{l}\text { A phase change } \\
\text { materials (PCM) } \\
\text { based battery } \\
\text { thermal } \\
\text { management was } \\
\text { designed and } \\
\text { experimentally } \\
\text { tested. In this } \\
\text { system, cylindrical } \\
\text { lithium-ion battery }\end{array}$ & $\begin{array}{l}\text { It was illustrated } \\
\text { that though this } \\
\text { configuration, the } \\
\text { temperature of the } \\
\text { battery cells at a } \\
\text { discharge rate of } \\
\text { 3C can be kept at } \\
\text { below } 44^{\circ} \mathrm{C} \text {, with a } \\
\text { temperature }\end{array}$ & $\begin{array}{l}\text { It was demonstrated } \\
\text { that heat pipe } \\
\text { assisted PCM based } \\
\text { battery thermal } \\
\text { management system } \\
\text { presents a very good } \\
\text { thermal performance, } \\
\text { keeping the } \\
\text { temperature of the } \\
\text { cell at below the }\end{array}$ \\
\hline
\end{tabular}




\begin{tabular}{|l|l|l|l|l|}
\hline system & $\begin{array}{l}\text { cells were placed } \\
\text { directly in the } \\
\text { blocks of PCM } \\
\text { material which act } \\
\text { as heat absorbers. } \\
\text { The PCM material } \\
\text { was then cooled } \\
\text { through a set of } \\
\text { heat pipes which } \\
\text { are place between } \\
\text { the PCM blocks. }\end{array}$ & nearly $2^{\circ} \mathrm{C}$. & & $\begin{array}{l}\text { maximum operating } \\
\text { temperature with a } \\
\text { uniform cell } \\
\text { temperature } \\
\text { distribution. }\end{array}$ \\
& & & \\
\hline
\end{tabular}

Following the above investigation, it can be concluded that different thermal boundary configurations require different thermal management techniques and methods. Xia et al. [113] also explains that when a cooling medium such as air or liquid is employed, the way which the coolant is passed through the battery pack must be carefully analysed and configured. This meant that for example, when the cooling configuration is set in a series arrangement, the heat absorbed by the coolant might be delivered to the cells which are located along and towards the end of the flow path, resulting in an uneven distribution of heat and even increase of temperature of the cells which are located towards the end of the path. On the other hand, for a parallel configuration, the flow rate may not be equally distributed though the battery cells, resulting again in an irregular distribution of between the cells.

On the other hand, direct cooling as demonstrated by Ren et al. [115] resulted in an increase of the cooling performance efficiency, which was mentioned to be due to the increased and direct contact between the battery cells and the cooling medium. Having said that and as presented by Al-Zareer et al. [116], Javani et al. [118] and Rao et al. [119], the use of Phase Change Materials (PCM) and heat pipe based configurations also provided promising results, in some cases eliminating the need for a complex system design and improving the overall system performance. Furthermore and as shown by Ling et al. [122] and Huang et al. [123], several successful attempts also have been made to improve the efficiency and effectiveness of these thermal management systems, generally by integrating and combining different methods and techniques with each other. Nevertheless and as discussed by Xia et al. [113] and Murashko et al. [120] the application of these technologies found out to be mainly dependent on parameters such as cost, size, compactness, and reliability of the overall system.

\section{Conclusion}

The functionality and applications of thermal management techniques used for batteries in industrial applications have been investigated and analysed. Through a state of the art literature review, different types of batteries and their applications were discovered and based on that, it was explained which batteries provide the best performance and what technologies can be used to manage their thermal boundaries. 
It has been explored how all batteries function based on an electrochemical process and how the operating performance of batteries depends largely on temperature. It was indicated that the internal chemical reaction in the batteries is activated either by temperature or voltage difference. It was also demonstrated that in simple terms the hotter the battery gets, the quicker the electrochemical process takes place. This, was further illustrated to be true until to a certain operating temperature. The rise in heat was investigated to also result in the increase of unwanted reactions within the battery which accordingly causes loss of battery capacity and an increase in self-discharge rate.

It was explained how such phenomena can be tackled through employing thermal management techniques and through heating and cooling methods. Based on this, it was shown that it is easier to thermally manage a battery that is suffering from low-temperature effects. The thermal management for this was demonstrated to be simply achieved by using the internal energy of the battery or from an external source.

To follow this, this paper also showed that techniques which can be employed to cool down batteries can be more complicated than the methods used for heating. These systems were indicated to make the use of several heat transfer principles to actively or passively take the generated heat away from batteries. The main advantages offered by cooling techniques was demonstrated to include dissipation of excessive heat, protection from overheating and uniform distribution of heat through the battery pack. Several evidences were also presented as to the suitability of air, liquid and evaporative cooling methods for batteries in varied power applications.

In conclusion, it was illustrated that it is vital to develop a battery thermal management configuration which can be used to prevent temperature increase and at the same time reduce the temperature of the cells, while keeping the temperature uniformity to a minimum. It was also shown that this way and through different thermal management systems, the life cycle and efficiency of the batteries can be improved. Nevertheless, it was demonstrated that different thermal management techniques and configurations offer different efficiency and performance. This meant that before applying a thermal management technique to a system, performance and condition parameters such as the optimum performance and configuration of the method used must be analysed. Overall, it can be claimed that as the demand for better batteries in terms of higher specific power, specific energy, longer life cycle and efficiency in increasing, the need for more proper thermal management systems and techniques is also more apparent, which can be used to achieve these goals.

\section{Acknowledgements}

This work has been funded by Innovate UK grants: 3941/133371 and 3921/133368.

\section{References}

[1] A. Foley and A. G. Olabi, "Renewable energy technology developments, trends and policy implications that can underpin the drive for global climate change,” Renew. Sustain. Energy Rev., vol. 68, pp. 1112-1114, Feb. 2017. 
[2] H. Jouhara and A. G. Olabi, “Editorial: Industrial waste heat recovery,” Energy, vol. 160, pp. 1-2, Oct. 2018.

[3] O. Schmidt, A. Hawkes, A. Gambhir, and I. Staffell, "The future cost of electrical energy storage based on experience rates,” Nat. Energy, vol. 2, no. 8, p. 17110, Jul. 2017.

[4] T. Wilberforce et al., "Developments of electric cars and fuel cell hydrogen electric cars," Int. J. Hydrogen Energy, vol. 42, no. 40, pp. 25695-25734, Oct. 2017.

[5] A.G. Olabi, "Energy quadrilemma and the future of renewable energy,” Energy, vol. 108, pp. 1-6, Aug. 2016.

[6] A. G. Olabi, S. O. Akansu, and N. Kahraman, "Fuel cell and energy storage systems: A special issue section on 'The 9th International Conference on Sustainable Energy and Environmental Protection (SEEP 2016), 22-25 September 2016, Kayseri, Turkey,'” Int. J. Hydrogen Energy, vol. 42, no. 40, pp. 25544-25549, Oct. 2017.

[7] R. Zhao, J. Gu, and J. Liu, "Performance assessment of a passive core cooling design for cylindrical lithium-ion batteries,” Int. J. Energy Res., Mar. 2018.

[8] X. Lin et al., "Parameterization and Observability Analysis of Scalable Battery Clusters for Onboard Thermal Management," Oil Gas Sci. Technol. - Rev. d'IFP Energies Nouv., vol. 68, no. 1, pp. 165-178, Jan. 2013.

[9] H. Teng, Y. Ma, K. Yeow, and M. Thelliez, "An Analysis of a Lithium-ion Battery System with Indirect Air Cooling and Warm-Up,” SAE Int. J. Passeng. Cars - Mech. Syst., vol. 4, no. 3, pp. 2011-01-2249, Sep. 2011.

[10] C. G. Motloch et al., "High-Power Battery Testing Procedures and Analytical Methodologies for HEV's," 2002.

[11] S. S. Zhang, K. Xu, and T. R. Jow, “The low temperature performance of Li-ion batteries,” J. Power Sources, vol. 115, no. 1, pp. 137-140, Mar. 2003.

[12] R. Hutchinson, "TEMPERATURE EFFECTS ON SEALED LEAD ACID BATTERIES AND CHARGING TECHNIQUES TO PROLONG CYCLE LIFE,” 2004.

[13] L. Energizer Brands, "Nickel Metal Hydride (NiMH) Handbook and Application Manual,” 2018.

[14] M. Ghassemi and E. Afshari, "Effect of Temperature Variation on Nickel Cadmium (Ni-Cd) and Nickel Metal Hydride (Ni-MH) Battery Parameters," in Volume 2, Parts A and B, 2004, pp. 1343-1352.

[15] M. D. Anderson and D. S. Carr, "Battery energy storage technologies," Proc. IEEE, vol. 81, no. 3, pp. 475-479, Mar. 1993.

[16] M. Khan, M. Swierczynski, and S. Kær, "Towards an Ultimate Battery Thermal Management System: A Review,” Batteries, vol. 3, no. 4, p. 9, Mar. 2017.

[17] J. Cen, Z. Li, and F. Jiang, "Experimental investigation on using the electric vehicle air conditioning system for lithium-ion battery thermal management,” Energy Sustain. Dev., vol. 45, pp. 88-95, Aug. 2018.

[18] J. N. D. Bernardi, E.Pawlikowski, “A general Energy Balance for Battery SystemsNo Title,” 1984.

[19] H. Liu, Z. Wei, W. He, and J. Zhao, "Thermal issues about Li-ion batteries and recent progress in battery thermal management systems: A review,” Energy Convers. Manag., vol. 150, pp. 304-330, Oct. 2017.

[20] A. Greco, "Numerical and Analytical Modelling of Battery Thermal Management using Passive Cooling Systems,” 2015. 
[21] L. Feng et al., "Experimental investigation of thermal and strain management for lithium-ion battery pack in heat pipe cooling,” J. Energy Storage, vol. 16, pp. 84-92, Apr. 2018.

[22] H. Liu, Z. Wei, W. He, and J. Zhao, "Thermal issues about Li-ion batteries and recent progress in battery thermal management systems: A review,” Energy Convers. Manag., vol. 150, pp. 304-330, Oct. 2017.

[23] R. Sabbah, R. Kizilel, J. R. Selman, and S. Al-Hallaj, “Active (air-cooled) vs. passive (phase change material) thermal management of high power lithium-ion packs: Limitation of temperature rise and uniformity of temperature distribution,” J. Power Sources, vol. 182, no. 2, pp. 630-638, Aug. 2008.

[24] D. Chen, J. Jiang, G.-H. Kim, C. Yang, and A. Pesaran, "Comparison of different cooling methods for lithium ion battery cells,” Appl. Therm. Eng., vol. 94, pp. 846-854, Feb. 2016.

[25] E. Soylu and R. Bayir, "Measurement of Electrical Conditions of Rechargeable Batteries," Meas. Control, vol. 49, no. 2, pp. 72-81, Mar. 2016.

[26] A. Alaswad, A. Baroutaji, H. Achour, J. Carton, and A. Al Makky, "Developments in fuel cell technologies in the transport sector," Int. J. Hydrogen Energy, vol. 41, no. 37, pp. 1649916508, Oct. 2016.

[27] J. B. Goodenough and K.-S. Park, “The Li-Ion Rechargeable Battery: A Perspective,” J. Am. Chem. Soc., vol. 135, no. 4, pp. 1167-1176, Jan. 2013.

[28] LiveScience, "How Do Batteries Work?,” 2015. [Online]. Available: https://www.livescience.com/50657-how-batteries-work.html. [Accessed: 24-Apr-2018].

[29] A. Mishra et al., "Electrode Materials for Lithium-ion Batteries," Mater. Sci. Energy Technol., Aug. 2018.

[30] Energizer, “How Do Batteries Work | Energizer,” 2018. [Online]. Available: http://www.energizer.com/about-batteries/how-do-batteries-work. [Accessed: 24-Apr-2018].

[31] Chris Woodford, "How do batteries work? A simple introduction - Explain that Stuff,” 2018. [Online]. Available: http://www.explainthatstuff.com/batteries.html. [Accessed: 24-Apr-2018].

[32] Woodbank Communications Ltd., "Primary (Non Rechargeable) Batteries,” 2005. [Online]. Available: https://www.mpoweruk.com/primary.htm. [Accessed: 07-Jul-2018].

[33] M. (Michel) Broussely and G. (Gianfranco) Pistoia, Industrial applications of batteries : from cars to aerospace and energy storage. Elsevier, 2007.

[34] Z. A. Zafar et al., “A super-long life rechargeable aluminum battery,” Solid State Ionics, vol. 320, pp. 70-75, Jul. 2018.

[35] Woodbank Communications Ltd., “Secondary - Rechargeable - Cells,” 2005. [Online]. Available: https://www.mpoweruk.com/lithiumS.htm. [Accessed: 07-Sep-2018].

[36] H. Budde-Meiwes et al., "A review of current automotive battery technology and future prospects Our storage demand study for Agora Energiewende View project highly porous cathode composite for Li-ion batteries View project A review of current automotive battery technology and future prospects," Artic. Proc. Inst. Mech. Eng. Part D J. Automob. Eng., 2013.

[37] C. M. Diniş, G. N. Popa, and A. Iagăr, "Study on sources of charging lead acid batteries," IOP Conf. Ser. Mater. Sci. Eng., vol. 85, no. 1, p. 012011, Jun. 2015.

[38] P. Ruetschi, "Review on the lead-acid battery science and technology,” J. Power Sources, vol. 2, no. 1, pp. 3-120, Dec. 1977.

[39] I. Buchmann and Cadex Electronics Inc., Batteries in a portable world : a handbook on rechargeable batteries for non-engineers. Cadex Electronics, 2001. 
[40] B. Hariprakash, S. A. Gaffoor, and A. K. Shukla, "Lead-acid batteries for partial-state-ofcharge applications,” J. Power Sources, vol. 191, no. 1, pp. 149-153, Jun. 2009.

[41] Battery World, “Battery World | Battery Acid \&amp; Water,” 2015. [Online]. Available: http://batteryworld.co.ke/battery-acid-water/. [Accessed: 27-Apr-2018].

[42] VelocityEHS, "Sulfuric Acid Safety Tips - Sulfuric Acid MSDS Information | MSDSonline," 2018. [Online]. Available: https://www.msdsonline.com/2014/07/22/sulfuric-acid-safety-tipssulfuric-acid-msds-information/. [Accessed: 27-Apr-2018].

[43] R. S. Treptow, “The Lead-Acid Battery: Its Voltage in Theory and in Practice,” J. Chem. Educ., vol. 79, no. 3, p. 334, Mar. 2002.

[44] G. J. May, A. Davidson, and B. Monahov, "Lead batteries for utility energy storage: A review,” J. Energy Storage, vol. 15, pp. 145-157, Feb. 2018.

[45] Barrie Lawson (Woodbank Communications Ltd.), "Lead Acid Batteries,” 2005. [Online]. Available: http://www.mpoweruk.com/leadacid.htm. [Accessed: 21-May-2018].

[46] D. Diemand, “Automoti’ve Batteries at Low Temperatures,” 1991.

[47] B. L. McKinney, G. L. Wierschem, and E. N. Mrotek, "Thermal Management of Lead-Acid Batteries for Electric Vehicles,” 1983.

[48] L. Zhang, “Batteries, Rechargeable,” Encycl. Mater. Sci. Technol., pp. 463-483, Jan. 2001.

[49] G. Min, “Power supply sources for smart textiles,” Smart Clothes Wearable Technol., pp. 214231, Jan. 2009.

[50] Philips Emergency Lighting, “NICKEL-CADMIUM Battery Advantages,” 2010.

[51] T. Sasaki, Y. Ukyo, and P. Novák, “Memory effect in a lithium-ion battery,” Nat. Mater., vol. 12, no. 6, pp. 569-575, Jun. 2013.

[52] M. C. McManus, "Environmental impacts of batteries for low carbon technologies compared," 2012.

[53] David Fox, "NiCd, Li-ion and NiMH CAMERA BATTERIES - THE PROS AND CONS WWW.URBANFOX.TV.” [Online]. Available:

http://www.urbanfox.tv/articles/batteries/b1batteries.html. [Accessed: 10-Jul-2018].

[54] Ian Poole, "NiMH Nickel Metal Hydride Battery Technology Overview :: RadioElectronics.Com.” [Online]. Available: https://www.radio-electronics.com/info/powermanagement/battery-technology/nimh-nickel-metal-hydride.php. [Accessed: 07-Sep-2018].

[55] S. R. Ovshinsky, M. A. Fetcenko, and J. Ross, "A Nickel Metal Hydride Battery for Electric Vehicles,” Science (80-. )., vol. 260, no. 5105, pp. 176-181, Apr. 1993.

[56] Brian Mok, “Types of Batteries Used for Electric Vehicles,” 2017.

[57] A. Ni, N. Cd, M. A. Zelinsky, J. M. Koch, and K. Young, "Performance Comparison of Rechargeable Batteries for Stationary Applications (Ni/MH vs. Ni-Cd and VRLA),” Batteries, vol. 4, no. 1, p. 1, 2017.

[58] L. J. Hardwick and C. P. de León, “Rechargeable Multi-Valent Metal-Air Batteries,” Johnson Matthey Technol. Rev., vol. 62, no. 2, pp. 134-149, 2018.

[59] J. Daniel-Lvad, "Rechargeable Alkaline TM Dioxide (RAM ) Cell Chemistry.”

[60] K. Kordesch and M. Weissenbacher, "Rechargeable alkaline manganese dioxide/zinc batteries,” 1994.

[61] M. E. Douglas, "ALKALINE SINGLE CELL BATTERIES AND RECHARGERS: RESULTS OF PRELIMINARY TESTS.” 
[62] E. Olivetti, J. Gregory, and R. Kirchain, "LIFE CYCLE IMPACTS OF ALKALINE BATTERIES WITH A FOCUS ON END-OF-LIFE.”

[63] Michael Bluejay, "Rechargeable Batteries explained in detail (NiMH, NiZn, NiCd, RAM)." [Online]. Available: https://michaelbluejay.com/batteries/rechargeable.html. [Accessed: 17Aug-2018].

[64] N. Nitta, F. Wu, J. T. Lee, and G. Yushin, "Li-ion battery materials: present and future," Mater. Today, vol. 18, no. 5, pp. 252-264, Jun. 2015.

[65] J. Fong, R., Vonsacken, U., and Dahn, J.R., "Studies of lithium intercalation into cabones using nonaqueous electrochemical cells,” Electrochem. Soc, vol. 137, no. 7, pp. 2009-2013, 1990.

[66] F. Schipper and D. Aurbach, "A Brief Review: Past, Present and Future of Lithium Ion Batteries 1,” Russ. J. Electrochem., vol. 52, no. 12, pp. 1229-1258, 2016.

[67] ABB, "Lithium-ion battery systems for ABB UPS solutions Reliable, lightweight and compact UPS energy storage for critical applications."

[68] C. Curry, "Lithium-ion Battery Costs and Market Squeezed margins seek technology improvements \&amp; new business models,” 2017.

[69] K. Kimura et al., "Improvement of the Cyclability and Coulombic Efficiency of Li-Ion Batteries Using Li[Ni $\left.{ }_{0.8} \mathrm{Co}_{0.15} \mathrm{Al}_{0.05}\right]_{\mathrm{O}_{2}}$ Cathode Containing an Aqueous Binder with Pressurized CO 2 Gas Treatment,” J. Electrochem. Soc., vol. 165, no. 2, pp. A16-A20, 2018.

[70] D. Project in Chemical Engineering and Joakim Andersson, "Lifetime estimation of lithiumion batteries for stationary energy storage systems.”

[71] Isidor Buchmann, "BU-502: Discharging at High and Low Temperatures - Battery University.”.

[72] Woodbank Communications Ltd., "Battery Performance Characteristics - How to specify and test a battery,” 2005. .

[73] B. Shabani and M. Biju, "Theoretical modelling methods for thermal management of batteries,” Energies, vol. 8, no. 9, pp. 10153-10177, 2015.

[74] J. Jaguemont, L. Boulon, and Y. Dubé, “A comprehensive review of lithium-ion batteries used in hybrid and electric vehicles at cold temperatures,” Appl. Energy, vol. 164, pp. 99-114, Feb. 2016.

[75] Battery University, "Charging Batteries at High and Low Temperatures - Battery University." [Online]. Available:

https://batteryuniversity.com/learn/article/charging_at_high_and_low_temperatures. [Accessed: 24-Sep-2018].

[76] Q. Wang, X. Zhao, J. Ye, Q. Sun, P. Ping, and J. Sun, "Thermal response of lithium-ion battery during charging and discharging under adiabatic conditions," J. Therm. Anal. Calorim., vol. 124, no. 1, pp. 417-428, 2016.

[77] L. H. Saw, A. A. O. Tay, and L. W. Zhang, "Thermal management of lithium-ion battery pack with liquid cooling," in 2015 31st Thermal Measurement, Modeling \& Management Symposium (SEMI-THERM), 2015, pp. 298-302.

[78] Á. L. István Lagzi, Róbert Mészáros, Györgyi Gelybó, “Arrhenius Equation.” [Online]. Available:

http://elte.prompt.hu/sites/default/files/tananyagok/AtmosphericChemistry/ch03s06.html. [Accessed: 25-Aug-2018].

[79] R.-E. Tudoroiu et al., "Real-Time Implementation of an Extended Kalman Filter and a PI Observer for State Estimation of Rechargeable Li-Ion Batteries in Hybrid Electric Vehicle 
Applications-A Case Study,” Batteries, vol. 4, no. 2, p. 19, Apr. 2018.

[80] Woodbank Communications Ltd., "Battery Life and How To Improve It,” 2005. [Online]. Available: https://www.mpoweruk.com/life.htm. [Accessed: 07-Aug-2018].

[81] Gianfranco Pistoia, “Rechargeable Batteries,” Batter. Portable Devices, pp. 77-146, Jan. 2005.

[82] E. Darcy, N.-J. Houston, U. F. Davies, U. J. Jeevarajan, and L. Martin, "Lithium-Ion Cell PTC Limitations and Solutions for High Voltage Battery Applications.”

[83] A. N. Zhoujian, J. Li, Y. Ding, D. Chao, and X. Li, "A Review on Lithium-ion Power Battery Thermal Management Technologies and Thermal Safety,” J. Therm. Sci., vol. 26, no. 5, pp. 391-412, 2017.

[84] L. Ghadbeigi, B. Day, K. Lundgren, and T. D. Sparks, "Cold temperature performance of phase change material based battery thermal management systems,” Energy Reports, vol. 4, pp. 303-307, Nov. 2018.

[85] Woodbank Communications Ltd, “Battery Thermal Management,” 2005. [Online]. Available: https://www.mpoweruk.com/thermal.htm. [Accessed: 21-Jul-2018].

[86] V. Zinth et al., "Lithium plating in lithium-ion batteries at sub-ambient temperatures investigated by in situ neutron diffraction,” J. Power Sources, vol. 271, pp. 152-159, Dec. 2014.

[87] Mohammad Rezwan Khan, "Aalborg Universitet Thermal Management of Battery Systems in Electric Vehicle and Smart Grid Application Khan, Mohammad Rezwan,” 2016.

[88] Littelfuse, "Resettable Over-temperature Protection Devices Boost LiP and Prismatic Battery Safety, Save Space - Littelfuse,” 2018. [Online]. Available: http://www.littelfuse.com/aboutus/press-releases/2018/09.10-resettable-over-temperature-protection-devices.aspx. [Accessed: 24-Sep-2018].

[89] I. Littelfuse, "Circuit Protection for Lithium-Ion and Lithium Polymer Rechargeable Battery Applications,” 2001.

[90] R. Hu, "Battery Management System For Electric Vehicle Applications,” 2011.

[91] A. A. Pesaran, "Battery Thermal Management in EVs and HEVs: Issues and Solutions."

[92] U. S. Rohatgi, "Thermal Characteristics of Air Flow Cooling in the Lithium Ion Batteries Experimental Chamber,” Puerto Rico, 2012.

[93] X. Na, H. Kang, T. Wang, and Y. Wang, "Reverse layered air flow for Li-ion battery thermal management,” Appl. Therm. Eng., vol. 143, pp. 257-262, Oct. 2018.

[94] S. Rabczak et al., "Qualitative thermal characterization and cooling of lithium batteries for electric vehicles Related content Influence of Shading on Cooling Energy Demand Qualitative thermal characterization and cooling of lithium batteries for electric vehicles,” J. Phys. Conf. Ser. OPEN ACCESS.

[95] Z. Lu, X. Z. Meng, W. Y. Hu, L. C. Wei, L. Y. Zhang, and L. W. Jin, “Thermal Management of Densely-packed EV Battery Set."

[96] Z. Lu, X. Z. Meng, L. C. Wei, W. Y. Hu, L. Y. Zhang, and L. W. Jin, "Thermal Management of Densely-packed EV Battery with Forced Air Cooling Strategies,” Energy Procedia, vol. 88, pp. 682-688, Jun. 2016.

[97] J. Jaguemont, N. Omar, P. Van den Bossche, J. Van Mierlo, and K. Adams, “Optimized passive thermal management for battery module," in 2017 20th International Conference on Electrical Machines and Systems (ICEMS), 2017, pp. 1-6.

[98] C. Huber, "Phase Change Material in Battery Thermal Management Applications An assessment of efficiency and safety,” 2017. 
[99] A. Alrashdan, A. T. Mayyas, and S. Al-Hallaj, "Thermo-mechanical behaviors of the expanded graphite-phase change material matrix used for thermal management of $\mathrm{Li}$-ion battery packs,” J. Mater. Process. Technol., vol. 210, no. 1, pp. 174-179, Jan. 2010.

[100] R. Sabbah, R. Kizilel, J. R. Selman, and S. Al-Hallaj, “Active (air-cooled) vs. passive (phase change material) thermal management of high power lithium-ion packs: Limitation of temperature rise and uniformity of temperature distribution,” J. Power Sources, vol. 182, no. 2, pp. 630-638, Aug. 2008.

[101] D. W. Lee, "DEVELOPMENT OF BLDC MOTOR AND MULTI-BLADE FAN FOR HEV BATTERY COOLING SYSTEM,” Int. J. Automot. Technol., vol. 15, no. 7, pp. 1101-1106, 2014.

[102] K. Chen et al., "Design of Parallel Air-Cooled Battery Thermal Management System through Numerical Study."

[103] X. Li, F. He, G. Zhang, Q. Huang, and D. Zhou, "Experiment and simulation for pouch battery with silica cooling plates and copper mesh based air cooling thermal management system," Appl. Therm. Eng., vol. 146, no. October 2018, pp. 866-880, 2019.

[104] Z. Rao, Z. Qian, Y. Kuang, and Y. Li, "Thermal performance of liquid cooling based thermal management system for cylindrical lithium-ion battery module with variable contact surface," Appl. Therm. Eng., vol. 123, pp. 1514-1522, Aug. 2017.

[105] M. Suresh Patil et al., "A Novel Design for Lithium ion Battery cooling using Mineral Oil,” 2016.

[106] Z. Shang, H. Qi, X. Liu, C. Ouyang, and Y. Wang, "Structural optimization of lithium-ion battery for improving thermal performance based on a liquid cooling system," Int. J. Heat Mass Transf., vol. 130, pp. 33-41, 2019.

[107] H. Ohno, J. Hatakeyama, M. Nagata, and T. Maeda, "New technologies Development of Waste Thermal Energy Recovery Heat Pump.”

[108] TOYOTA, "Pillars of the 2016 Prius: new-generation hybrid system - Toyota," 2016. [Online]. Available: http://blog.toyota.co.uk/pillars-of-the-2016-prius-new-generation-hybrid-system. [Accessed: 25-Sep-2018].

[109] Synergy Files, “A review of Battery Thermal Management System - Synergy Files,” 2018. [Online]. Available: http://synergyfiles.com/2016/07/battery-thermal-management-systemreview/. [Accessed: 25-Sep-2018].

[110] Al-Zareer M, Dincer I, Rosen MA. Novel thermal management system using boiling cooling for high-powered lithium-ion battery packs for hybrid electric vehicles. J Power Sources 2017;363:291-303. doi:10.1016/J.JPOWSOUR.2017.07.067.

[111] R. A. P. Bambang Ariantara, Nandy Putra, "Performance of Flat Plate Loop Heat Pipe for Thermal Management of Lithium-Ion Battery in Electric Vehicle Application,” 2015.

[112] J. Smith, R. Singh, M. Hinterberger, and M. Mochizuki, "Battery thermal management system for electric vehicle using heat pipes,” Int. J. Therm. Sci., vol. 134, pp. 517-529, Dec. 2018.

[113] G. Xia, L. Cao, and G. Bi, “A review on battery thermal management in electric vehicle application,” J. Power Sources, vol. 367, pp. 90-105, 2017.

[114] F. He and L. Ma, "Thermal management of batteries employing active temperature control and reciprocating cooling flow,” Int. J. Heat Mass Transf., vol. 83, pp. 164-172, Apr. 2015.

[115] Y. Ren, Z. Yu, and G. Song, "Thermal management of a Li-ion battery pack employing water evaporation,” J. Power Sources, vol. 360, pp. 166-171, Aug. 2017.

[116] M. Al-Zareer, I. Dincer, and M. A. Rosen, "Novel thermal management system using boiling cooling for high-powered lithium-ion battery packs for hybrid electric vehicles,” J. Power 
Sources, vol. 363, pp. 291-303, Sep. 2017.

[117] C. Lan, J. Xu, Y. Qiao, and Y. Ma, "Thermal management for high power lithium-ion battery by minichannel aluminum tubes,” Appl. Therm. Eng., vol. 101, pp. 284-292, May 2016.

[118] N. Javani, I. Dincer, G. F. Naterer, and B. S. Yilbas, "Heat transfer and thermal management with PCMs in a Li-ion battery cell for electric vehicles,” Int. J. Heat Mass Transf., vol. 72, pp. 690-703, May 2014.

[119] Z. Rao, S. Wang, M. Wu, Z. Lin, and F. Li, "Experimental investigation on thermal management of electric vehicle battery with heat pipe," Energy Convers. Manag., vol. 65, pp. 92-97, Jan. 2013.

[120] K. Murashko, J. Pyrhonen, and L. Laurila, "Optimization of the passive thermal control system of a lithium-ion battery with heat pipes embedded in an aluminum plate," in 2013 15th European Conference on Power Electronics and Applications (EPE), 2013, pp. 1-10.

[121] X. H. Yang, S. C. Tan, and J. Liu, “Thermal management of Li-ion battery with liquid metal,” Energy Convers. Manag., vol. 117, pp. 577-585, 2016.

[122] Z. Ling, F. Wang, X. Fang, X. Gao, and Z. Zhang, “A hybrid thermal management system for lithium ion batteries combining phase change materials with forced-air cooling," Appl. Energy, vol. 148, pp. 403-409, 2015.

[123] Q. Huang, X. Li, G. Zhang, J. Zhang, F. He, and Y. Li, "Experimental investigation of the thermal performance of heat pipe assisted phase change material for battery thermal management system,” Appl. Therm. Eng., vol. 141, pp. 1092-1100, Aug. 2018. 